\title{
The impact of temporary employment on productivity
}

\section{The importance of sectors' skill intensity}

\author{
Domenico Lisi ${ }^{1} \cdot$ Miguel A. Malo ${ }^{2}$
}

Accepted: 21 February 2017 / Published online: 9 March 2017

(c) The Author(s) 2017. This article is available at SpringerLink with Open Access.

\begin{abstract}
Recent papers in the economic literature emphasise that the use of temporary contracts (TE) could have a detrimental effect on productivity. However, there are different reasons to believe that the impact of TE might not be homogeneous across sectors. In this article, we study the impact of TE on productivity growth and, in particular, we wonder if it differs according to sectors' skill intensity. Our data set is an industry-level panel of European countries that allows to divide sectors according to the skill intensity. Our main result is that TE has a negative impact on productivity growth, but it is more damaging in skilled sectors. While an increase of 10 percentage points of the share of TE in skilled sectors would decrease labour productivity growth of about $1-1.5 \%$, in unskilled sectors the decrease would be of $0.5-0.8 \%$. This result is robust to different skill intensity indexes and productivity measures, as well as to the sample composition. We also discuss policy implications of this result for labour market regulation.
\end{abstract}

Keywords Productivity $\cdot$ Temporary employment $\cdot$ Skill intensity $\cdot$ Differential effect

JEL Classification J41 $\cdot$ J24 $\cdot$ O47

Domenico Lisi

domenico.lisi@unict.it

Miguel A. Malo

malo@usal.es

1 Department of Economics and Business, University of Catania, Corso Italia 55, 95129 Catania, Italy

2 Universidad de Salamanca, Salamanca, Spain

\section{Auswirkungen befristeter Beschäftigung auf die Produktivität}

Die Bedeutung der Qualifikationsintensität von Branchen

Zusammenfassung Jüngste wirtschaftswissenschaftliche Abhandlungen betonen, dass die Nutzung befristeter Arbeitsverträge einen negativen Einfluss auf die Produktivität haben könnte. Es sprechen jedoch verschiedene Gründe dafür, dass die Auswirkungen befristeter Arbeitsverträge nicht in allen Branchen gleich sind. In diesem Artikel untersuchen wir den Einfluss von befristeten Arbeitsverträgen auf das Produktivitätswachstum und fragen insbesondere, ob es je nach der Qualifikationsintensität der Branchen Unterschiede gibt. Unser Datensatz ist ein Panel europäischer Länder auf Wirtschaftszweigebene, das es uns gestattet, die Branchen nach Qualifikationsintensität zu unterscheiden. Unser wichtigstes Ergebnis ist, dass befristete Beschäftigung einen negativen Einfluss auf das Produktivitätswachstum hat, dies aber in Branchen mit hoher Qualifikationsintensität stärkere negative Auswirkungen hat. Während ein Anstieg des Anteils an befristeter Beschäftigung in qualifikationsintensiven Branchen um 10 Prozentpunkte das Produktivitätswachstum um rund $1-1,5 \%$ senken würde, betrüge dieser Wert in weniger qualifikationsintensiven Branchen nur rund 0,5-0,8\%. Dieses Ergebnis ist stabil für verschiedene Intensitätsindices und Produktivitätsmaßnahmen sowie für die Stichprobenzusammensetzung. Des Weiteren behandeln wir politische Auswirkungen dieses Ergebnisses für die Arbeitsmarktregulierung.

\section{Introduction}

Following the widespread diffusion of temporary employment (TE) in European countries, a large concern has been 
growing about direct and side negative effects of increasing flexibility of labour markets. The recent flexibility reforms had been introduced with the aim of removing labour market rigidities, which in the supply-side thinking (see e.g., OECD 1999, 2003; IMF 2007) were seen as the main cause of stagnant labour markets, under the implicit assumption that more flexible conditions for workers would not affect innovative capacity and productivity growth (Vergeer and Kleinknecht 2014). In this regard, however, most recent papers studying the role of TE in different European countries, and employing different empirical approach, find a negative and significant impact of TE on innovation and productivity (Ortega and Marchante 2010; Cappellari et al. 2012; Lisi 2013; Kleinknecht et al. 2014). Furthermore, the recent macro stylized-facts and, principally, the growthless job creation condition have drawn even more attention on the impact of flexibility reforms on productivity (Boeri and Garibaldi 2007; OECD 2007).

The main objective of this paper consists in studying the impact of the share of TE on productivity, explicitly considering the differential effect in skilled and unskilled economic sectors. From this perspective, we go beyond to the current literature arguing that there are good reasons to suspect that the impact of TE could differ significantly according to sectors' skill intensity. For this purpose, we build an industry-level panel of European countries that allows to divide sectors according to the skill intensity.

This research connects with the wide spreading concern about cost-saving flexibility reforms in general and, in particular, temporary contracts. In fact, the debate both in the literature and in public institutions has been moving from promoting all types of flexibilization of labour markets to fight 'Euroesclerosis' (OECD 1994), toward criticizing TE as a form of flexibility at the margin (Boeri and Garibaldi 2009), especially because temporary contracts are found to damage the career prospects for young people (Cazes and Tonin 2010; OECD 2015), decrease the provision of onthe-job training by firms (Albert et al. 2005, 2010), reduce workers' earnings (Booth et al. 2002; Garz 2013) and, as a side effect, negatively affect aggregate labour productivity (Kleinknecht 1998; Vergeer and Kleinknecht 2011, 2014). In this perspective, it seems highly relevant to study the role of sectors' skill intensity behind the impact of TE, as the different channels of transmission through which TE affects productivity, which we discuss below, could have a different role according to skills' intensity by industry.

To the best of our knowledge, this is the first study that attempts to investigate the impact of TE differentiated according to sectors' skill intensity. Our main result is that TE is even more damaging in skilled sectors, with a negative effect significantly heavier than in unskilled sectors, and this would seem robust to little changes in the skill intensity index and in the sample used, as well as to different productivity measures. In particular, an increase of 10 percentage points of the share of TE in skilled sectors would lead to a decrease of about $1-1.5 \%$ in labour productivity growth, whereas in unskilled ones the reduction would be of $0.5-0.8 \%$. To some extent, this result might support the idea that TE is currently used more as a cheaper form of job, instead of as a least-cost way of screening new workers (Booth et al. 2002; Güell and Petrongolo 2007; Autor and Housman 2010; Garz 2013).

The paper proceeds as follows. Sect. 2 provides the background for the empirical analysis, with the previous literature on TE, flexibilization and productivity. In Sect. 3 we present the empirical analysis, focusing on the strategy to disentangle the impact of TE across sectors. Then, Sect. 4 describes the characteristics of our dataset and main variables. In Sect. 5 we present our estimates and provide different robustness checks. Finally, Sect. 6 collects the main conclusions of this study.

\section{Background}

\subsection{Theoretical arguments}

The labour market reforms of the last decades have been introduced with the objective of relaxing the rigidities and, thus, making labour markets more flexible. In particular, European flexibility reforms concentrated in the so-called "numerical" (external) flexibility that allows firms to adjust their workforce by flexible firing and hiring, and "wage" flexibility concerning the wage-setting institutions (Boeri and Garibaldi 2009; Vergeer and Kleinknecht 2014). ${ }^{1}$ As a result, this process of flexibilization has led to labour markets increasingly characterized by lower employment protection (EPL) for regular workers and larger use of atypical contracts for hiring new workers (Lucidi and Kleinknecht 2010; Walwei 2014; Eichhorst and Tobsch 2015; ILO 2016). ${ }^{2}$

The theoretical support for flexibilization policies, coming especially from the supply-side thinking (OECD 2003; IMF 2007), was usually grounded under the implicit assumption that more flexible labour markets would not af-

\footnotetext{
${ }^{1}$ In our study, we focus more on the effect of "numerical" flexibility on productivity growth, to emphasize the role of sectors' skill intensity. For a recent study concerning the effect of weak wage growth on productivity, see Vergeer and Kleinknecht (2014).

2 In principle, one might expect that temporary workers would receive a risk premium above the normal wage, for the higher risk of becoming unemployed. In practice, however, temporary workers appear to earn less on average respect to regular workers, as showed by large literature (Booth et al. 2002; McGinnity and Mertens 2004). Therefore, as emphasized by Vergeer and Kleinknecht (2014), labour market reforms concerning "numerical" and "wage" flexibility seem to work in the same direction of lowering the firms' wage bill.
} 
fect innovative capacity and productivity growth, but only firms' willingness to hire new workers and, thus, the level of unemployment. In addition, temporary work might lead to other advantages, as they might allow firms to decrease costs (Houseman 2001), a more efficient screening to select better workers (Wang and Weiss 1998; Autor 2001) or represent a buffer to take advantage of short-term positive shocks (Bentolila and Saint-Paul 1992; Goux et al. 2001). As we will see later, there is some empirical evidence supporting these theoretical predictions, especially for the case of temporary agency workers (TAW). Nevertheless, there is an increasing body of literature reasoning that TE might potentially affect labour productivity. Hereunder, we briefly discuss a few major channels between TE and productivity ${ }^{3}$, following the recent literature on labour market flexibilization (e. g., Lucidi and Kleinknecht 2010; Kleinknecht et al. 2014).

Firstly, temporary workers might be less willing to cooperate with their employers in developing innovations, as they presumably will not enjoy in any way the expected benefit from them (Kleinknecht 1998). Indeed, this argument might be especially relevant for TAW, who are not formally workers of the user firm. Furthermore, temporary workers might be more inclined to develop general skills, which increase their future employability in the labour market, than firm-specific skills if there is no long-term commitment with employers (MacLeod and Navakachara 2007). Moreover, the option of hiring new temporary workers implies that firms have no incentive to invest in "functional" (internal) flexibility, which instead might be favourable to develop innovation and enhance productivity growth (Michie and Sheehan 2003; Zhou et al. 2011). Therefore, a significant presence of TE might potentially frustrate firms' innovative capacity.

Another channel of transmission through which TE might negatively affect productivity is the presumable negative effect on workforce training. In fact, temporary contracts are of too short duration, thereby reducing the firms' incentive to invest in training, given the short payback period of the investment for fixed-term workers and, even more so, for TAW. However, if firms confine temporary workers to jobs requiring low qualification and/or low experience, the impact on productivity of their lower training may be negligible. In this respect, several empirical studies tend to confirm that temporary workers in European countries have less access to on-the-job training provided by firms (Alba-Ramirez 1994; Booth et al. 2002; OECD 2007; Albert et al. 2005, 2010). Nonetheless, the cross-country evidence provided by Bassanini et al. (2005)

\footnotetext{
${ }^{3}$ For a discussion on the major channels through which "wage" flexibility reforms could potentially affect productivity growth, see Vergeer and Kleinknecht (2014).
}

shows that the negative correlation between temporary contracts and lower training is strongly due to the inclusion of Spain in the sample, while excluding this country the correlation does not longer hold. ${ }^{4}$

Previous literature on personnel economics suggests that "high-trust" human resource management practices can generate favourable productivity effects (Lorenz 1999; Buchele and Christiansen 1999; Naastepad and Storm 2006). According to these theories, long-lasting working relations are an investment in trust and commitment between employees and employers, which might boost productivity growth. On the opposite, temporary contracts might be interpreted as a firms' choice to not commit in long-lasting relations and, thus, TE might dampen productivity. However, because temporary employment helps the adjustment of workforce to address demand shocks, temporary work might have a positive effect on labour productivity (Hagen 2003).

Finally, looking at the workers' effort as a relevant component of total factor productivity (TFP), in countries where "temp-to-perm" conversion rates are low and, thus, employers appear to use TE more as a cheaper form of job (Houseman 2001; Booth et al. 2002; Güell and Petrongolo 2007; Garz 2013), it might be rationale for temporary workers to exert a lower effort respect to permanent workers (Lisi 2012; Dolado et al. 2016), eventually reducing productivity. This might be especially true for TAW, for which the evidence in the literature does not lend empirical support to the stepping stone hypothesis (Kvasnicka 2009; Autor and Housman 2010).

In analysing the impact of temporary work on absenteeism, however, Jimeno and Toharia (1996) and Ichino and Riphahn (2005) find that the threat of losing their jobs decreases absenteeism in temporary workers respect to those with open-ended contracts. In a similar vein, Malo and Sánchez-Sánchez (2014) reason that, as temporary workers have a higher probability of losing their jobs than permanent workers, they have a lower probability of being involved in labour conflicts with a positive effect on labour productivity.

Therefore, the impact of temporary employment on labour productivity remains ambiguous at theoretical level and might depend on their use and amount in the specific firms and sectors, which calls for the empirical evidence.

\footnotetext{
${ }^{4}$ In this regard, Albert et al. (2005) find that temporary workers in Spain are less likely to be employed by firms providing training and, furthermore, they have a lower probability of being trained when hired in firms providing training activities.
} 


\subsection{Previous evidence}

The empirical literature on the impact of temporary employment on productivity is rather large, and different (and not converging) empirical findings have emerged, depending also on the type of temporary employment. A few previous studies as Arvanitis (2005) and Nielen and Schiersch (2016) find no effects of temporary contracts using panel data at the firm level. On the other hand, Damiani and Pompei (2010) analyze multi-factor productivity across European countries and, as for the effect of temporary contracts, they find mixed results. In particular, though they find a negative impact of fixed-term arrangements, they also underline that labour provisions for the protection of fixed-term contracts may offset the negative effects deriving from a pure increase in temporary workers. The evidence seems more convergent on the positive impact of temporary agency work (TAW) on productivity (Bryson, 2013). Specifically, Hirsch and Mueller (2012) and Nielen and Schiersch (2014) find an inversely u-shaped relationship between the share of TAW and firms' performance. This interesting finding appears well-grounded in the argument that a low share of TE within a firm could be a means of enhancing numerical flexibility (Vidal and Tigges 2009) and screening new workers (Autor 2001), whereas a high share of TE could be a signal of a broader substitution between perms to temps, which is likely to lower the motivation and commitment of the workforce. In this respect, however, Nielen and Schiersch (2016) show that the same inversely u-shaped effect does not emerge for temporary contracts. Therefore, productivity effects of temporary employment may depend on their use and type in the economy or in the specific sector.

Nevertheless, in the last years many empirical studies find evidence supporting the arguments on negative effects of flexible jobs on productivity. For instance, Auer et al. (2005) find a positive relationship between job tenure and labour productivity. Similarly, in a panel of EU countries Lisi (2013) finds that an increase of the share of flexible jobs would lead to a decrease in labour productivity growth, even after controlling for the potential endogeneity of TE in the productivity equation.

Among country-specific studies, Kleinknecht et al. (2006) find a not significant impact of temporary contracts in Dutch manufacturing firms as a whole, but they also find different results when they distinguish between innovative and non-innovative firms. Among innovators, temporary employment seems to have no effect on labour productivity growth; on the other hand, among non-innovating firms a higher rate of people on temporary contracts, as well as more workers hired from private manpower agencies, decreases labour productivity growth. However, these estimated effects are hardly significant at conventional levels, with the exception of the negative effect of temporary contracts among non-innovators. Still in the Netherlands, Kleinknecht et al. (2014) find that high shares of temporary workers have a negative impact on the firms' investment in R\&D, especially in those sectors with a "routinised" innovation regime. Looking at the Italian context, Boeri and Garibaldi (2007) find a negative effect of the share of fixed-term contracts on labour productivity growth in a sample of manufacturing firms. Similarly, Lucidi and Kleinknecht (2010) show that high shares of flexible workers, high labour turnover and lower costs of labour are significantly related to lower labour productivity growth. Cappellari et al. (2012) look specifically at the two Italian reforms concerning the "external" flexibility, concluding that while the reform of apprenticeship had a positive impact on productivity, the reform of fixed-term contract generated a negative effect on productivity. Finally, Ortega and Marchante (2010) analyse the impact of the increase in the use of TE in Spain, finding that productivity growth has been slowed down by the extensive use of temporary contracts as a regular form of jobs.

Overall, all these studies estimate an average effect of TE on productivity. ${ }^{5}$ However, there are good reasons to suspect that the impact of TE could differ significantly according to sectors' skill intensity, as the different channels of transmission through which TE affects productivity could have a different role according to skills' intensity by industry.

For instance, we argued that temporary workers might be more inclined to develop general skills than firm-specific skills (MacLeod and Navakachara 2007), and this might affect labour productivity differently among industries according to the relative importance of specific human capital respect to general human capital in each industry. Furthermore, a lack of on-the-job training for temporary workers implies low levels of skill acquisition (Ortega and Marchante 2010), and this potential cost could be higher in those sectors in which work-related training has more importance. Similarly, as mentioned before, Bassanini et al. (2005) find a significant correlation between temporary contracts and training only when including Spain in their sample; therefore, how the lower access to training of temporary workers affects productivity remains an empirical issue. Finally, temporary contracts provide different incentives respect to permanent ones and, thus, temporary workers might exert a different effort in their jobs (Dolado et al. 2016), which might affect labour productivity differently according to sectors' skill intensity.

\footnotetext{
5 The only exception appears to be Ortega and Marchante (2010), which state that the effect of TE on productivity growth "... has only been detected in the manufacturing and energy sector, in contrast to low-technology low-human capital sectors ...", in line with the following results in our paper. Respect to Ortega and Marchante (2010), however, our following estimates do not refer to a specific country, but to a large panel of EU countries.
} 
Interestingly, the different arguments on the differential effect of TE between skilled and unskilled sectors would seem to depend on the way in which temporary contracts are used in the labour market. In particular, in skilled sectors the use of TE might potentially be more oriented towards screening new workers respect to unskilled ones, and this perspective could induce in temporary workers a higher motivation to develop firm-specific skills and exert higher effort (Engellandt and Riphahn 2005), as well as a higher firms' willingness to provide on-the-job training. On the other hand, if TE is used in the market as a structural cheaper form of job, in skilled sectors the cost in terms of lack of workforce training and lower workers' effort could be heavier, leading to an even greater effect in labour productivity growth (Dolado et al. 2016).

The opposite arguments concerning the differential effect of TE on productivity call for the empirical analysis. In the following, we aim to contribute to this literature by explicitly considering the differential effect of TE in skilled and unskilled sectors. ${ }^{6}$

\section{Empirical analysis}

In this section, we show the empirical strategy employed in the study to disentangle the impact of TE across sectors and, in particular, we describe the method used to divide industries between skilled and unskilled sectors. Then, we discuss the main advantages, but also the potential drawbacks, of our empirical specification.

In our empirical analysis, we modify earlier productivity equations in the literature (Bassanini and Venn 2008; Bassanini et al. 2009; Lucidi and Kleinknecht 2010; Lisi 2013), adapting the model to estimate the differential impact of TE across sectors. Our starting point is that the impact of TE on productivity might not be homogenous across sectors and, in particular, we wonder if the effect differs according to sectors' skill intensity. Therefore, dividing industries between skilled sectors (S) and unskilled sectors (US), we specify the following assumption (1) according to which the difference between the conditional expected productivity growth in the $\mathrm{S}$ group and in the US group is some function of the share of TE:

$\overline{\Delta \operatorname{lny}}_{i t}^{\mathrm{S}}-\overline{\Delta \operatorname{lny}}_{i t}^{\mathrm{US}}=f\left(\mathrm{TE}_{i j t}\right)$

\footnotetext{
6 The reader will note that we do not have data to disentangle the separate effect of each abovementioned channel through which TE might affect labour productivity. However, as highlighted by Lucidi and Kleinknecht (2010), even if such data were available, one would encounter substantial multi-collinearity problems, given that all channels between TE and productivity appear to work in the same direction.
}

where the first element indicates the conditional expected productivity growth in the $\mathrm{S}$ group in country $i$ at time $t$, the second one the same for the US group and $T E$ is the share of TE in country $i$ in sector $j$ at time $t$. In particular, the productivity growth in (1) are conditional in the sense that our assumption is valid after that all the other explanatory variables affecting productivity growth have been netted out; on the other hand, productivity growth are $e x$ pected in the sense that in (1) they are the average across all sectors within the two groups. Finally, notice that with respect to the standard diff-in-diff assumption where only observations in the treatment group are treated, in our case we assume that is the impact of the treatment to be different between the two groups. To this extent, our assumption is very close to the spirit of the method introduced by Rajan and Zingales (1998) to evaluate the impact of market regulations.

From the empirical perspective, to divide industries between skilled sectors (S) and unskilled sectors (US) we compute the ratio between skilled and unskilled workers in each sector for different years and, then, we consider the mean across time as a general index of sector's skill intensity (see e. g., Haskel and Slaughter 2002). Finally, we take the mean of these indexes across sectors and consider (un)skilled those sectors with a skill intensity (lower) higher than the average. This procedure leads us to the binary indicator $S S I I_{\mathrm{j}}$, which is equal to 1 if $j$ is a skilled sector and equal to 0 if $j$ is an unskilled one, that is:

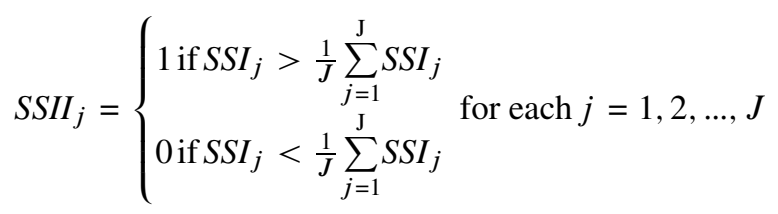

This indicator $S S I I_{\mathrm{j}}$ will be used in the productivity equation to disentangle the effect of the share of TE between skilled and unskilled sectors.

To make our results easily comparable with previous studies, we estimate also the impact of labour market regulation for regular workers, using the EPL index for PE as explanatory variable. As standard in this literature, to estimate the impact of EPL for PE we follow the method introduced in the finance literature by Rajan and Zingales (1998), then extended in labour (Bassanini and Venn 2007, 2008). The main assumption of this approach is that, while the degree of labour market regulation is equal for all industries in a country, the impact of it could be different among industries, according to some "physiological" characteristics of each sector. In particular, we expect that EPL is more binding in those industries characterized by a higher need 
to reallocate resources ${ }^{7}$ and, accordingly, in the productivity equation we interact the EPL for PE with the frictionless job reallocation rate $F J R_{\mathrm{j}}$ for each sector, depurated from labour market frictions and aggregate shocks. ${ }^{8}$ More specifically, the underlying assumption usually specified in the literature is (Bassanini et al. 2009; Cingano et al. 2010; Lisi 2013):

$\overline{\Delta \operatorname{lny}}_{i j t}-\overline{\Delta \operatorname{lny}}_{i k t}=f\left(F J R_{j}-F J R_{k}\right) \times \mathrm{EPL}_{i t}$

which states that the difference between the conditional expected productivity growth in two sectors $j$ and $k$, in country $i$ at time $t$, is a function of the degree of regulation weighted by the natural need of job reallocation in these sectors.

Finally, as suggested by the Schumpeterian growth literature (Griffith et al. 2004, 2009; Aghion and Howitt 2006), in our productivity equation at the industry level we include the lagged productivity gap between each observation and the industry leader, to control for possible catching-up. Indeed, the inclusion of the productivity gap should control also for exceptional fluctuations in capacity utilisation, which might be important to capture strongly misleading productivity increases (Lucidi and Kleinknecht 2010). Similarly, a few papers in the literature (Griffith et al. 2004, 2009; Bassanini and Venn 2007; Bassanini et al. 2009) suggest that the model of productivity growth for nonfrontier industries (i.e. for those observations at the industry level that are not on the frontier) should include as explanatory variable the contemporaneous productivity growth of the industry leader; specifically, this would require to include the contemporaneous productivity growth of the industry leader in the complete model (i. e. including nonfrontier and frontier industries) imposing the frontier growth term equal to 0 for the industry leaders. ${ }^{9}$

\footnotetext{
${ }^{7}$ For instance, as argued in Lisi (2013) “... if firms in a sector need to lay off workers in response to changes in technologies or product demand, a stricter EPL could slow the pace of reallocation. By contrast, in industries where changes are less frequent or where firms can reallocate labour through internal adjustments, EPL could be expected to have little impact on reallocation and, in turn, on productivity ...".

8 To obtain the frictionless job reallocation rate $F J R_{\mathrm{j}}$ for each sector, we follow the method developed by Ciccone and Papaioannou (2006) and, then, employed by different previous studies in this literature (e. g., Cingano et al. 2010; Lisi 2013). In particular, we regress the actual job reallocation rates at industry level on industry dummies $\pi_{j}$, industry dummies interacted with the EPL index for PE $\tau_{j} \times \mathrm{EPL}_{i t}$ and country-time dummies $\vartheta_{i t}: J R_{i j t}=\pi_{j}+\tau_{j} \times \mathrm{EPL}_{i t}+\vartheta_{i t}+v_{i j t}$. The presence of country-time dummies $\vartheta_{i t}$ should control for any time-varying differences across countries, whereas the interaction term $\tau_{j} \times \mathrm{EPL}_{i t}$ should absorb the effect of market regulation on job reallocation rate, allowing us to obtain an appropriate estimate $F J R_{j}=\widehat{\pi}_{j}$ of natural rate of job reallocation in each industry.

9 As suggested by Griffith et al. (2004) “... Augmenting the specification for nonfrontier countries with an additional term in contemporaneous frontier TFP growth allows for a more flexible relationship between nonfrontier and frontier TFP ...”; thus, for the sake of comple-
}

Therefore, if we assume a linear functional form $f$ in (1) and (3), the main specification of our empirical model is (Bassanini and Venn 2007, 2008; Lisi 2013):

$$
\begin{aligned}
\Delta \operatorname{lny}_{\mathrm{ijt}}= & \alpha+\beta \Delta \operatorname{lng} \mathrm{j}_{\mathrm{jt}}^{\mathrm{L}}+\eta \ln \left(\frac{\mathrm{y}_{\mathrm{ijt}-1}}{\mathrm{y}_{\mathrm{jt}-1}^{\mathrm{L}}}\right)+\delta \mathrm{TE}_{\mathrm{ijt}} \\
& +\gamma\left(S S I I_{\mathrm{j}} \times \mathrm{TE}_{\mathrm{ijt}}\right)+\zeta \mathrm{EPL}_{\mathrm{it}} \\
& +\theta\left(F J R_{\mathrm{j}} \times \mathrm{EPL}_{\mathrm{it}}\right)+\lambda \mathrm{X}_{\mathrm{ijt}}+\mu_{\mathrm{i}}+\varphi_{\mathrm{t}}+\varepsilon_{\mathrm{ijt}}
\end{aligned}
$$

where the dependent variable is the productivity growth (either labour productivity or TFP) in country $i$ in sector $j$ in year $t$ (measured as logarithmic difference). Then, the explanatory variables include:

- the productivity growth of the industry productivity leader $\Delta \ln _{\mathrm{j} t}^{\mathrm{L}}$,

- the lagged productivity gap with respect to the industry leader $\ln \left(y_{i j t-1} / y_{j t-1}^{L}\right)$,

- the share of temporary employment $\mathrm{TE}_{i j t}$,

- the EPL index for regular worker EPL $\mathrm{EL}_{i t}$,

- other control variables affecting productivity growth $X_{i j t}$, such as trade union density (TUD) and product market regulation $(P M R)^{10}$, including also the capital-tolabour growth $\Delta \operatorname{lnk}_{\mathrm{ijt}}$ when the empirical model (4) is for labour productivity ${ }^{11}$,

- vectors of country $\mu_{i}$ and time-specific $\varphi_{t}$ fixed effects.

In our model, $\gamma$ is the main coefficient of interest, the differential impact of TE on productivity growth in skilled sectors compared to unskilled ones. On the other hand, $\delta$ represents the impact of TE in unskilled sectors, and its inclusion is important since it allows the differential impact $\gamma$ to adjust upon a non-zero impact in unskilled sectors.

teness, we decided to include also this term in our productivity equation. However, all estimates with the inclusion of industry-specific fixed effects instead of the productivity growth of the industry leader produce a very similar pattern of results. Indeed, the limited influence of the contemporaneous productivity growth of the industry leader in the estimates is fully in line with the previous evidence in the literature (see e. g., Griffith et al. 2004, 2009; Bassanini et al. 2009).

$10 \mathrm{We}$ also tried to include some other explanatory variable potentially relevant in explaining productivity growth, such as tax wedge and unemployment benefits. Overall, they appear not significant, even if in some specifications without the EPL index and TUD they are significant. Indeed, this is not surprising given the high cross-country correlations among labour market institutions in OECD countries (OECD 2007; Bassanini et al. 2009). We therefore suspect that this result emerges because of multicollinearity and, for this reason, we preferred to keep them out from our estimates.

11 Notice that, as shown in the previous literature on industry-level productivity equation (see e.g., Bassanini and Venn 2007, 2008; Lisi 2013), when we consider the labour productivity growth as dependent variable in (4), the empirical model (4) is derived directly from an industry-level Cobb-Douglas production function and, thus, it includes the capital-labour ratio as regressor. 
Looking at the impact of the EPL index for PE, $\theta$ is the marginal impact of EPL in a sector with a relative high FJR compared to a sector with a relatively low FJR; this implies that, if the estimated coefficient is negative, productivity growth in high FJR sectors decreases with respect to that in low FJR ones, meaning that EPL for PE have a negative impact on productivity growth (Cingano et al. 2010).

A potential drawback of specification (4) is that it produces consistent estimates under the strictly exogeneity of all covariates, which might not be the case in our empirical analysis. In particular, to the extent that hiring a temporary worker is a firm's decision, the share of TE might be endogenous in the productivity equation. Therefore, following Lisi (2013) we perform also an IV-strategy, using the EPL index for TE as an instrumental variable for the share of TE. ${ }^{12}$ In particular, the main idea in our IV-strategy is that the country legislation concerning the use of temporary contracts certainly affect the share of TE, like so the variation of the legislation affects the share over time. In this regard, the EPL index for TE turns out to be significantly correlated ( $p$-value $=0.000)$ with the share of TE in our sample. Differently, the legislation about TE should not have any impact on productivity except for the actual use of temporary contracts; in fact, as long as temporary contracts are not used in the labour market, a change in the legislation would be expected to have no impact on productivity. ${ }^{13}$

We estimate several versions of our model, considering both labour productivity and TFP as dependent variable. Following the previous literature (Bassanini et al. 2009; Lucidi and Kleinknecht 2010), we have also repeated all our estimates including a vector of industry-specific fixed effects instead of the contemporaneous productivity growth of the industry leader, without changing at all our results. Moreover, as a few previous studies find an inversely u-shaped productivity effect of TAW (Hirsch and Mueller 2012; Nielen and Schiersch 2014), we also estimate

\footnotetext{
12 As a standard practice with an interaction term with endogenous regressors (i. e. TE*SSII), in our IV estimates we use the interaction term EPL index for TE*SSII as an instrument for the differential effect TE*SSII.

13 As standard in the IV-procedure, while we can easily test for the correlation between instrument and instrumented variable, we cannot test for the exogeneity condition of our instrument. Nonetheless, in the literature this kind of instrument (index measuring the strictness of a national legislation) tend to be considered strictly exogenous in the productivity equation, because their effect should be only indirect and, in particular, generated only by the change induced in the specific object of the regulation (in our case, the EPL index for TE should induce an effect in productivity growth only by the change induced in the share of TE). For example, OECD (2004) and Bassanini et al. (2009) use the EPL index for TE following the same argument, whereas Amable and Ledezma (2013) use the product market regulation index as an exogenous instrumental variable. Moreover, in a previous general article on temporary work and productivity, the EPL index for TE has already been used in IV estimations (Lisi 2013).
}

model (4) adding the quadratic term of the share of TE, to test whether the interaction term TE*SSII picks up the effect of non-linearity of TE in the productivity equation and, thus, leads to a wrong inference on the differential effect of TE among sectors. Finally, we provide different sensitivity checks, concerning the sectors' skill intensity index and the sample used in our estimates, to test the robustness of our findings.

Overall, our empirical specifications follow the previous literature on the topic. However, instead of estimating an average impact of TE across sectors, in our paper we estimate the differential impact of TE according to sectors' skill intensity. On the one hand, this should provide a more accurate description of the impact of TE; on the other hand, the investigation of this differential impact might offer some insight on how temporary contracts are currently used in the labour market (that is, least-cost way of screening new workers or cheaper form of job).

A troubling point in our empirical analysis regards the specifications using labour productivity as dependent variable. Indeed, while the model for TFP follows the intent to explain what factors affect its law of motion, the empirical model (4) for labour productivity is derived directly from an industry-level Cobb-Douglas production function, which clearly includes also the capital-labour ratio. ${ }^{14}$ In this respect, however, previous studies in this literature (OECD 2007; Bassanini and Venn 2008; Cingano et al. 2010; Cappellari et al. 2012) have estimated reduced-form models as (4) for labour productivity omitting the capital-labour ratio, in order to capture the overall effect of the policy of interest on labour productivity. On the other hand, different papers focusing on firm-level production function have shown that omitting capital-labour ratio as regressor in the empirical model for labour productivity could bias the estimates (e. g., Levinson and Petrin 2003). Therefore, in order to provide a robust evidence on the differential effect of TE, in our empirical analysis we provide estimates both with and without the capital-labour ratio in the model for labour productivity.

A potential drawback of our empirical specification is related to our assumption concerning the differential effect of TE across sectors. In particular, if the use of TE changes extensively the skill composition of our sectors (i. e. the socalled "composition effect", see Sect. 4) and, in turn, the selection of them in S- and US-sectors, then our assumption would not be useful anymore. In fact, in that case we are not exploiting the exogenous variation on the impact of TE between $\mathrm{S}$ - and US-sectors, because groups themselves are endogenously determined by the share of TE. Differently,

\footnotetext{
${ }^{14}$ For a formal derivation of the empirical model (4) from an industrylevel Cobb-Douglas production function, see e.g. Bassanini and Venn (2007) and Lisi (2013).
} 
if sectors' skill composition and, in turn, S- and US-groups are exogenously set by sectors' production functions, then our specification should allow us to estimate consistently the differential impact of TE across sectors.

Indeed, in line with the previous literature (e. g., OECD 2007; Cappellari et al. 2012) the clear picture emerging from our data is that the correlation between the share of TE and sectors' skill composition is almost null. In particular, in Fig. 1 we report the scatter plot between TE and SSI and, as we can see, the cloud would suggest that there is no correlation. Furthermore, the small and statistically insignificant correlation coefficient $(\rho=-0.037)$ also indicates that there is no correlation between TE and SSI. Therefore, the different skill composition across sectors would seem more driven by the technology underpinning the production function in each sector, which leads us to pursue our empirical strategy to estimate the differential impact of TE on productivity.

Finally, a potential problem in our IV strategy concerns the source of variation which is exploited in the productivity equation through the use of our instrument (i.e. the EPL index for TE). Specifically, if the legislation on the use of TE is strongly correlated with the social and cultural traits in a country, then the variation in the share of TE induced by a difference in the EPL index for TE among countries may retrace differences in the social and cultural aspects that may, in turn, affect productivity. If this is the case, indeed, the source of variation exploited in our IV-strategy might not be useful anymore, as it might be already included in our productivity equation (4) through the inclusion of country fixed effects $\mu_{i}$, potentially capturing also social and cultural aspects of a country. On the contrary, if the EPL index for TE is not (or only slightly) correlated with the social and cultural traits of countries in our sample, then the variation we exploit in the IV-strategy would not be included in the productivity equation (4) and, thus, it has the potential to offer an exogenous source of variation

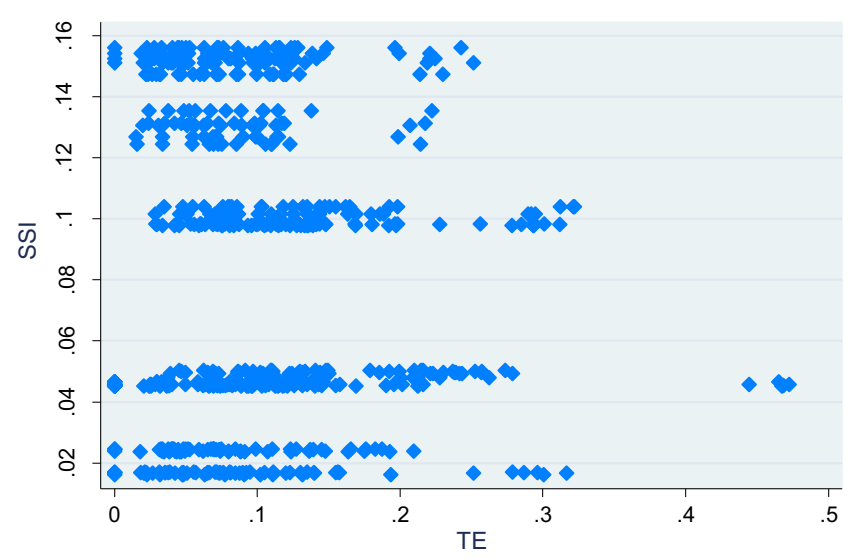

Fig. 1 Correlation between TE and SSI in the share of TE allowing us to estimate consistently the impact of TE on productivity.

In this regard, following the previous literature on this topic (e. g., Tabellini 2008, 2010; Aghion et al. 2010; OECD 2011; Charron et al. 2014, 2015), we found six indicators concerning social and cultural traits under different perspectives, for all European countries in our sample. ${ }^{15}$ Overall, the EPL index for TE turns out to be not (or very slightly) correlated with the abovementioned indicators of social and cultural traits ${ }^{16}$, suggesting that the variation exploited in our IV-strategy should represent a valuable source of variation to estimate the impact of TE in the productivity equation (4). Moreover, in Sect. 5 we provide the results of different statistical tests supporting further the use of our instrument.

\section{Database and main variables}

In our empirical analysis, we use an industry-level panel of EU countries. As emphasized by the previous literature, the advantage of using a panel of industry-level data is fourfold. First, not only the cross-country variation is still exploited, but also the variation on the impact of policies in different industries. Second, in contrast to the cross-country analysis, it potentially allows to control for unobserved fixed effects. Third, as the previous literature emphasised (e.g., OECD 2007) and as confirmed by our preliminary evidence (see Sect. 3), the within-industry "composition effect" appears to be negligible, allowing us to capture the "independent effect" of TE. ${ }^{17}$ Fourth, to the extent that events in a single

\footnotetext{
15 The issue of the indicators of social and cultural traits in a country has been always a big challenge in the literature (for a discussion on this issue, see e. g., Tabellini 2008, 2010) and, indeed, it is difficult to find indicators available for all European countries in our sample. In particular, the abovementioned six indicators of social and cultural traits, looking at the cultural aspects of a country under different perspectives, are mainly based on the previous literature (e. g., Tabellini 2008, 2010; Aghion et al. 2010; OECD 2011, Charron et al. 2014, 2015): trust, the fraction of survey respondents believing that "most people can be trusted" (Source: European Social Survey); respect, the fraction of survey respondents who claim to consider "tolerance and respect for others" as an important quality (Source: European Social Survey); pro-social behavior, averages responses to three questions about whether the respondent has volunteered time, donated money to a charity and helped a stranger in the last month (Source: Gallup World Poll); average years of schooling (Source: UNESCO Institute for Statistics); European quality of governance indicators 2010 and 2013 (Source: Charron et al. 2014, 2015).

${ }^{16}$ More specific results on the correlation between the EPL index for $\mathrm{TE}$ and the abovementioned indicators of social and cultural traits are available upon request form the authors.

17 In the literature the impact of a labour market policy on productivity is usually divided into "composition effect" and "independent effect". The first is the effect on productivity associated with the change in the composition of employment due to the policy variation (for instan-
} 
industry are not so relevant alone to affect the policy in a country, the specification is less subject to the simultaneity problem between the variable of interest and policy.

In particular, the dataset covers 10 sectors in 13 countries over the years 1992-2007, for a balanced panel of $2080 \mathrm{ob}-$ servations. Countries included are Austria, Belgium, Denmark, Finland, France, Germany, Ireland, Italy, the Netherlands, Portugal, Spain, Sweden and the United Kingdom. Since we make use of different data sources, we did some aggregation and the final sectors classification is based on the standard EUROSTAT classification (see Appendix B for details). The sectors are the following: "Agriculture, hunting and forestry", "Manufacturing", "Electricity, gas and water supply", "Construction", "Wholesale and retail trade", "Hotels and restaurants", "Transport, storage and communication", "Financial intermediation", "Real estate, renting and business activities", "Other community, social, personal service activities". With this sectors classification, we will define two aggregate groups of skill intensity consisting of five sectors with enough variability for our empirical analysis.

To collect our dataset we made use of different sources. The data on labour productivity, total factor productivity and employment level at the industry-level were collected from EU KLEMS dataset (www.euklems.net). This comprehensive database contains data on economic growth, productivity, employment and other variables at the industrylevel for all EU countries, providing an important source for policy evaluation.

The labour productivity measure used is the "gross value added per hour worked, volume indices, $1995=100 "$ ", defined in the following way:

$y_{i j t}=\frac{(V A / L)_{i j t}}{(V A / L)_{i j 1995}} \times 100$

where $V A$ is the gross value added in volumes and $L$ is the total amount of hours worked. Respect to other measures, the index measure with value added in volumes has different advantages and, in fact, it is the productivity measure largely most used in the literature (OECD 2007; Bassanini and Venn 2008; Cingano et al. 2010; Cappellari et al. 2012).

ce, an increase in the share of unskilled workers). The second is the pure average effect of the policy on productivity (that is, ceteris paribus) and, thus, it is often the effect of interest. In this regard, different previous studies emphasize that "composition effects" are somewhat relevant in the aggregate analysis and, indeed, they cannot be easily dismissed. Therefore, any aggregate analysis of the impact of some labour market policies on productivity hardly will be able to isolate the "independent effect" of the policy and, in turn, to produce a useful contribution for policy guidance. Differently, industry-level analyses suggest that the within-industry "composition effects" are fairly negligible (OECD 2007) and, therefore, the use of industry-level panel data should succeed in capturing the "independent effect" of the policy.
Looking at the behaviour over time, the mean of labour productivity in the entire sample is 110.94 , whereas the mean from 1995 (base year $=100$ ) is 114.31 , telling us that labour productivity grew in EU countries, even if not so significantly.

The other indicator we use for productivity is total factor productivity (TFP) or multi-factor productivity. In the economic literature, this variable is obtained as a residual, as it is defined as the effects on total output not caused by the inputs considered in the aggregate production function (typically, labour and capital). TFP is often seen as the main driver of economic growth, mirroring the long-term technological change. The TFP measure used is the "TFP, $1995=$ $100 "{ }^{18}$ Unfortunately, no data on TFP at the industry-level are available for Portugal; therefore, in the estimates considering TFP as dependent variable data for Portugal are not included. Looking at the behaviour over time, the mean of TFP in the entire sample is 103.74 , whereas the mean from 1995 (base year $=100$ ) is 104.96, telling us that TFP growth in EU countries in the last years has been very scarce.

The data on capital stock were collected from OECD STAN database, a comprehensive tool for analyzing industrial performance across countries. In particular, the capital stock measure used is the "CPGK - gross capital stock in volume terms". Unfortunately, no data on capital stock at the industry-level are available for Ireland, Portugal and Sweden; therefore, in the estimates including the capitallabour ratio in the productivity equation these countries are dropped.

The shares of TE at the industry-level were constructed from EU Labour Force Survey launched by the EUROSTAT (see Appendix A for details) ${ }^{19}$ and, as far as we know, it is the only industry-level measure of TE available for such large sample of countries. A potential limitation of this measure, however, is that it does not allow to distinguish between fixed-term contracts and temporary agency workers. Indeed, as discussed in Sect. 2, these two types of temporary employment might generate different effects on labour productivity and, thus, distinguishing between them might be relevant in our study. Moreover, though temporary agency employment levels grew strongly in all European countries over the period (CIETT 2009), still the use of TAW is rather heterogeneous among them (see Appendix B, Table B.4), which implies that also the composition of TE is somewhat mixed in our sample. In fact, while in a few countries TAW represent a significant part of temporary employment as

\footnotetext{
${ }^{18}$ The two productivity measures correspond respectively to $L P \_I$ and TFPva_I in EU KLEMS database.

19 The EUROSTAT definition of temporary contracts is the following: "Employees with temporary contracts are those who declare themselves as having a fixed term employment contract or a job which will terminate if certain objective criteria are met, such as completion of an assignment or return of the employee who was temporarily replaced".
} 
in the United Kingdom (64\%) and France (16\%), in other countries as in Spain (2\%), Portugal (4\%) and Italy (6\%) the use of temporary work agency appears to be less relevant, despite they exhibit among the highest share of TE in Europe. Therefore, a bit of caution in the interpretation of our results and in the subsequent policy implications seems appropriate.

As for the behaviour of TE in our sample, the mean and standard deviation of the share of TE are respectively 0.12 and 0.10 , confirming that TE is an important feature of the labour market landscape in Europe by this time, but its importance differs significantly across countries. For instance, while in countries as Spain (0.32) and Portugal (0.16) the share of TE is far away from the mean, in the UK the mean is no more than 0.06 (see Appendix B, Table B.3). Interestingly, the share of TE turns out to be negatively correlated with labour productivity and total factor productivity, both cross-country $\left(\rho_{L P_{i}}=-0.2972, \rho_{\mathrm{TFP}_{i}}=-0.3224\right)$ and crossindustry $\left(\rho_{L P_{j}}=-0.4836, \rho_{\mathrm{TFP}_{j}}=-0.2481\right)$.

To construct our sectors' skill intensity index, we divide workers between skilled and unskilled using two main indicators. Indeed, the idea initially was to use more than two indicators, to test as much as possible our results. However, all other plausible indicators led us to the same dichotomy among sectors of those two. For both indicators the data are collected from Science, technology and innovation database (EUROSTAT), which collects data from many different publications on these themes as R\&D expenditure, workers knowledge, HRST, innovations.

The first indicator concerns the level of education and we consider skilled those workers with a tertiary education (level 5-6 ISCED 1997). Differently, the second indicator concerns the kind of task workers make in their job. In particular, the database gives us these values as a share of total employment, for each sector from 2001 to 2007. Notice that, actually, the time period of our analysis is wider than 2001-2007; unfortunately, data availability on the above mentioned indicators prevents us to construct our SSII using the same time period. Therefore, in our empirical analysis we are forced to rely on the assumption that 2001-2007 represents a consistent time period to split the industries, which could potentially be reasonable but still we need to rely on this assumption in our empirical analysis. In this regard, the idea to employ more than one indicator has been also driven by the intent to test our results by an alternative subdivision of sectors. Overall, these two indicators lead us to a similar, but still slightly different, subdivision of sectors (see Appendix B).

As measure of EPL for PE we made use of the cardinal index constructed by OECD (2004). In our sample from 1992 to 2007 the EPL index for PE ranges from 4.33 in Portugal (1992-2003) to 0.95 in the UK (1992-1999). The mean of the index follows a slightly decreasing trend, going from 2.47 to 2.33 at the end of the sample. However, the decreasing trend in the stringency of regulation of PE is far from being common to all countries, rather it seems to be driven by Spain and Portugal. On the other hand, the EPL index for TE ranges from 5.38 in Italy (1992-1996) to 0.25 in the UK (1992-2001). Similarly to PE, the mean of the index for TE follows a decreasing trend, going from 2.92 to 1.86 . But differently to PE, this decreasing trend seems to be a common feature in fairly all EU countries.

Data on trade union density were collected from ICTWSS database, providing information on institutional characteristics of trade unions in 34 countries between 1960 and 2007. In particular, the variable used is "the ratio of wage and salary earners that are trade union members, divided by the total number of wage and salary earners". The mean in the sample is 0.40 , telling us how trade union are still an important subject in Europe. However, the standard deviation of 0.23 suggests how different is its importance across EU countries. Finally, product market regulation indicators used are the OECD Indicators of PMR, a comprehensive set of indicators measuring the degree to which policies promote or inhibit competition. In our sample $P M R$ exhibits much variation, revealing that these policies are not homogenous in Europe.

A full description of variables and sources can be found in Appendix A, whereas different descriptive statistics, penetration rates of TAW among countries and the subdivisions of sectors between skilled and unskilled are reported in Appendix B.

\section{Discussion of results}

In this section, we present and discuss the main results of the empirical analysis. Table 1 shows the estimates from different specifications of model (4). In particular, columns (1) to (3) use labour productivity as dependent variable, whereas (4) to (6) use TFP. Then, in Table 2 we provide the estimates of the model for labour productivity including the capital-labour ratio.

More specifically, in column (1) we report the coefficients of the baseline model, a POLS regression without any fixed effects. Both point estimates of TE and TE*SSII are negative and significant, suggesting that $\mathrm{TE}$ is even more damaging in skilled sectors, with a negative effect significantly heavier than in unskilled sectors. Similarly, the point estimate of EPL*FJR is negative and significant, confirming the previous evidence on the negative effect of EPL for PE (Bassanini et al. 2009; Cingano et al. 2010). Both the growth of productivity frontier and relative productivity gap appear to be significantly associated with productivity growth with the expected sign; moreover, estimated coefficients seem to be in line with estimates found in the previous literature (Griffith et al. 2004, 2009; Bassanini et al. 2009). In particular, the negative sign of the relative pro- 
Table 1 Temporary employment and productivity growth

\begin{tabular}{|c|c|c|c|c|c|c|}
\hline & \multicolumn{3}{|l|}{$\Delta \log \mathrm{LP}$} & \multicolumn{3}{|l|}{$\Delta \log$ TFP } \\
\hline & (1) & (2) & (3) & (4) & (5) & (6) \\
\hline & POLS & FE & IV & POLS & FE & IV \\
\hline$\overline{\Delta \text { Log Productivity }}{ }^{\mathrm{L}}$ & $\begin{array}{l}0.158 \\
(0.024) * * *\end{array}$ & $\begin{array}{l}0.211 \\
(0.028)^{* * *}\end{array}$ & - & $\begin{array}{l}0.150 \\
(0.026) * * *\end{array}$ & $\begin{array}{l}0.213 \\
(0.031)^{* * *}\end{array}$ & - \\
\hline Log Relative Productivity & $\begin{array}{l}-0.022 \\
(0.008) * * *\end{array}$ & $\begin{array}{l}-0.023 \\
(0.009)^{* *}\end{array}$ & $\begin{array}{l}-0.020 \\
(0.010)^{* *}\end{array}$ & $\begin{array}{l}-0.021 \\
(0.012)^{*}\end{array}$ & $\begin{array}{l}-0.032 \\
(0.014)^{* *}\end{array}$ & $\begin{array}{l}-0.019 \\
(0.012) *\end{array}$ \\
\hline EPL & $\begin{array}{l}0.009 \\
(0.003) * * *\end{array}$ & $\begin{array}{l}0.010 \\
(0.007)^{*}\end{array}$ & $\begin{array}{l}0.009 \\
(0.002) * * *\end{array}$ & $\begin{array}{l}0.011 \\
(0.003) * * *\end{array}$ & $\begin{array}{l}0.009 \\
(0.005)^{*}\end{array}$ & $\begin{array}{l}0.010 \\
(0.002) * * *\end{array}$ \\
\hline EPL*FJR & $\begin{array}{l}-0.166 \\
(0.051)^{* * *}\end{array}$ & $\begin{array}{l}-0.178 \\
(0.052) * * *\end{array}$ & $\begin{array}{l}-0.110 \\
(0.040) * * *\end{array}$ & $\begin{array}{l}-0.140 \\
(0.053)^{* * *}\end{array}$ & $\begin{array}{l}-0.146 \\
(0.053)^{* * *}\end{array}$ & $\begin{array}{l}-0.111 \\
(0.032) * * *\end{array}$ \\
\hline TE & $\begin{array}{l}-0.040 \\
(0.017)^{* * *}\end{array}$ & $\begin{array}{l}-0.056 \\
(0.022)^{* *}\end{array}$ & $\begin{array}{l}-0.087 \\
(0.052)^{*}\end{array}$ & $\begin{array}{l}-0.061 \\
(0.015)^{* * *}\end{array}$ & $\begin{array}{l}-0.051 \\
(0.021)^{* *}\end{array}$ & $\begin{array}{l}-0.112 \\
(0.047)^{* * *}\end{array}$ \\
\hline TE*SSII & $\begin{array}{l}-0.071 \\
(0.017) * * *\end{array}$ & $\begin{array}{l}-0.081 \\
(0.018) * * *\end{array}$ & $\begin{array}{l}-0.043 \\
(0.011)^{* * *}\end{array}$ & $\begin{array}{l}-0.016 \\
(0.011)^{*}\end{array}$ & $\begin{array}{l}-0.017 \\
(0.009)^{* *}\end{array}$ & $\begin{array}{l}-0.018 \\
(0.011)^{*}\end{array}$ \\
\hline TUD & $\begin{array}{l}-0.001 \\
(0.001)_{-}\end{array}$ & $\begin{array}{l}-0.002 \\
(0.001)^{*}\end{array}$ & $\begin{array}{l}-0.005 \\
(0.003)^{*}\end{array}$ & $\begin{array}{l}-0.001 \\
(0.001)_{-}\end{array}$ & $\begin{array}{l}-0.002 \\
(0.004)_{-}\end{array}$ & $\begin{array}{l}-0.003 \\
(0.004)_{-}\end{array}$ \\
\hline PMR & $\begin{array}{l}-0.001 \\
(0.000)^{* * *}\end{array}$ & $\begin{array}{l}-0.001 \\
(0.001)_{-}\end{array}$ & $\begin{array}{l}-0.008 \\
(0.002) * * *\end{array}$ & $\begin{array}{l}-0.001 \\
(0.001)_{-}\end{array}$ & $\begin{array}{l}-0.001 \\
(0.002)_{-}\end{array}$ & $\begin{array}{l}-0.001 \\
(0.002)_{-}\end{array}$ \\
\hline CONSTANT & $\begin{array}{l}0.021 \\
(0.005)^{* * *}\end{array}$ & - & - & $\begin{array}{l}0.013 \\
(0.004) * * *\end{array}$ & - & - \\
\hline COUNTRY DUMMIES & NO & YES & YES & NO & YES & YES \\
\hline YEAR DUMMIES & NO & YES & YES & NO & YES & YES \\
\hline SECTOR DUMMIES & $\mathrm{NO}$ & NO & YES & NO & NO & YES \\
\hline Endogeneity Test ${ }^{\mathrm{a}}$ & - & - & $p$-val $=0.02$ & - & - & $p$-val $=0.10$ \\
\hline F-statistics ${ }^{\mathrm{b}}$ & - & - & 59.971 & - & - & 71.132 \\
\hline Observations & 1950 & 1950 & 1950 & 1800 & 1800 & 1800 \\
\hline $\mathrm{R}$-squared & 0.115 & 0.191 & 0.431 & 0.117 & 0.168 & 0.247 \\
\hline
\end{tabular}

$P O L S$ pooled ordinary least squares, $F E$ fixed effects (dummy variable regression), $I V$ instrumental variable, $E P L$ employment protection legislation, $F J R$ frictionless job reallocation, $T E$ the share of temporary employment, $T U D$ trade union density, $P M R$ product market regulation

HAC Robust standard errors in brackets

$*$ significant at $10 \%, * *$ significant at $5 \%, * * *$ significant at $1 \%$

${ }^{a}$ The endogeneity test is the difference of two Sargan-Hansen statistics: one for the equation with the smaller set of instruments and one for the equation with the larger set of instruments. Unlike the Hausman tests, this statistic is robust to heteroskedasticity and serial correlation

${ }^{b} \mathrm{~F}$-statistic of the Kleibergen-Paap rk Wald test for weak identification

ductivity gap suggests the presence of catching-up effects in productivity growth. Finally, the coefficient of PMR also appears to be significant, suggesting that product market regulations have a negative effect on productivity growth (Nicoletti and Scarpetta 2003). While these estimates are useful to get an insight on the direction of the effect, they cannot be interpreted as consistent, given the omitted variable bias and the potential endogeneity of TE in the productivity equation.

Therefore, in column (2) we introduce a large set of country and time-specific fixed effects, controlling for institutional and time differentials in productivity growth, allowed to be correlated with other explanatory variables. Still, the coefficients of TE and TE*SSII are negative and significant. Similarly, all other estimated coefficients maintain the same sign, but now also the coefficient of TUD appear significant, suggesting that a higher share of unionized employees has a negative effect on productivity growth. Fi- nally, in column (3) we report the estimates of our IV model, where we use the EPL index for TE as an instrument for the share of TE (and EPL*SSII for TE*SSII), along with the results of different tests. As we can see, the endogeneity test in Table 1 tends to confirm that the share of TE is, indeed, endogenous in the productivity equation, implying that we need to implement the IV-strategy to estimate consistently the impact of TE (Lisi 2013). Likewise, the KleibergenPaap weak identification test reports a significantly high value of the F-statistic ${ }^{20}$, saying that the EPL index for TE and its interaction with SSII are not weak instruments in

\footnotetext{
${ }_{20}$ As for the Kleibergen-Paap rk Wald statistic, Baum et al. (2007) suggest to apply the critical values for the F-statistic reported in Stata provided by Stock and Yogo (2005). In particular, if we are willing to accept an actual rejection rate of $10 \%$ (the lowest tabulated in Stata), the critical value for the F-statistic is 16.38. Therefore, the KleibergenPaap statistic of 59.971 in (3) indicates that the EPL index for TE and its interaction with SSII are not weak instruments in our IV estimate.
} 
Table 2 Temporary employment and labour productivity growth $(\mathrm{K} / \mathrm{L})$

\begin{tabular}{|c|c|c|c|}
\hline & \multicolumn{3}{|l|}{$\Delta \log \mathrm{LP}$} \\
\hline & (1) & (2) & (3) \\
\hline & POLS & $\mathrm{FE}$ & IV \\
\hline$\Delta \log \mathrm{K} / \mathrm{L}$ & $\begin{array}{l}0.294 \\
(0.038) * * *\end{array}$ & $\begin{array}{l}0.343 \\
(0.037) * * *\end{array}$ & $\begin{array}{l}0.236 \\
(0.019)^{* * *}\end{array}$ \\
\hline$\Delta$ Log Productivity ${ }^{\mathrm{L}}$ & $\begin{array}{l}0.101 \\
(0.018) * * *\end{array}$ & $\begin{array}{l}0.135 \\
(0.021) * * *\end{array}$ & - \\
\hline Log Relative Productivity & $\begin{array}{l}-0.023 \\
(0.008)^{* * *}\end{array}$ & $\begin{array}{l}-0.030 \\
(0.008)^{* *}\end{array}$ & $\begin{array}{l}-0.022 \\
(0.011)^{* *}\end{array}$ \\
\hline EPL & $\begin{array}{l}0.008 \\
(0.003) * *\end{array}$ & $\begin{array}{l}0.008 \\
(0.008)\end{array}$ & $\begin{array}{l}0.006 \\
(0.003) * *\end{array}$ \\
\hline EPL*FJR & $\begin{array}{l}-0.100 \\
(0.048)^{* *}\end{array}$ & $\begin{array}{l}-0.116 \\
(0.057)^{* *}\end{array}$ & $\begin{array}{l}-0.082 \\
(0.038)^{* *}\end{array}$ \\
\hline $\mathrm{TE}$ & $\begin{array}{l}-0.039 \\
(0.018)^{* *}\end{array}$ & $\begin{array}{l}-0.066 \\
(0.024)^{* * *}\end{array}$ & $\begin{array}{l}-0.062 \\
(0.036)^{*}\end{array}$ \\
\hline TE*SSII & $\begin{array}{l}-0.054 \\
(0.017)^{* * *}\end{array}$ & $\begin{array}{l}-0.067 \\
(0.022)^{* * *}\end{array}$ & $\begin{array}{l}-0.088 \\
(0.019)^{* * *}\end{array}$ \\
\hline TUD & $\begin{array}{l}-0.001 \\
(0.001)_{-}\end{array}$ & $\begin{array}{l}-0.003 \\
(0.001)^{* * *}\end{array}$ & $\begin{array}{l}-0.005 \\
(0.003)^{*}\end{array}$ \\
\hline PMR & $\begin{array}{l}-0.001 \\
(0.000) * *\end{array}$ & $\begin{array}{l}-0.001 \\
(0.001)_{-}\end{array}$ & $\begin{array}{l}-0.009 \\
(0.002)^{* * *}\end{array}$ \\
\hline CONSTANT & $\begin{array}{l}0.012 \\
(0.005) * *\end{array}$ & - & - \\
\hline COUNTRY DUMMIES & NO & YES & YES \\
\hline YEAR DUMMIES & NO & YES & YES \\
\hline SECTOR DUMMIES & NO & NO & YES \\
\hline Endogeneity Test ${ }^{\mathrm{a}}$ & - & - & $p$-val $=0.01$ \\
\hline F-statistics ${ }^{b}$ & - & - & 30.983 \\
\hline Observations & 1500 & 1500 & 1500 \\
\hline R-squared & 0.189 & 0.246 & 0.511 \\
\hline
\end{tabular}

$P O L S$ pooled ordinary least squares, $F E$ fixed effects (dummy variable regression), $I V$ instrumental variable, $E P L$ employment protection legislation, FJR frictionless job reallocation, $T E$ the share of temporary employment, $T U D$ trade union density, $P M R$ product market regulation

HAC Robust standard errors in brackets

$*$ significant at $10 \%$, ** significant at $5 \%$, *** significant at $1 \%$

a The endogeneity test is the difference of two Sargan-Hansen statistics: one for the equation with the smaller set of instruments and one for the equation with the larger set of instruments. Unlike the Hausman tests, this statistic is robust to heteroskedasticity and serial correlation

${ }^{b}$ F-statistic of the Kleibergen-Paap rk Wald test for weak identification

our IV estimate. Nonetheless, even if different in magnitude respect to (2), both the estimated coefficients of TE and TE*SSII are still negative and significant. Similarly, all other estimated coefficients maintain the same sign and, furthermore, in (3) both the coefficient of TUD and PMR appear to be significant.

Since we are able to control for several unobserved factors, as well as for the endogeneity of the share of TE, we interpret the estimated effects as consistent and, in particular, the coefficient of TE*SSII as the differential effect of temporary employment on productivity growth between skilled and unskilled sectors. Our central result is that TE is even more damaging in skilled sectors, with a negative effect significantly heavier than in unskilled sectors. Specifically, an increase of 10 percentage points of the share of TE in skilled sectors would lead to a decrease of about $1-1.5 \%$ in labour productivity growth, whereas in unskilled ones the reduction would be only of $0.5-0.8 \%$.

Notice that, in Lisi (2013) it is found a higher average effect of TE respect to our results, that is a decrease of about $2-3 \%$ in labour productivity. Indeed, this might appear a remarkable difference considering that, apart from the estimation of the differential effect of TE across sectors, we employ a similar dataset and empirical method. More specifically, the few differences respect to Lisi (2013) are given by the inclusion of Schumpeterian variables and product market regulation in the productivity equation, along with a slightly (i. e. two years) longer time period of our sample. In this regard, running the same IV estimate in Lisi (2013) with our longer sample, we find fairly similar results but a slightly lower average effect of TE (i. e. -0.233); on the other hand, including the Schumpeterian variables and 
Table 3 Temporary employment and productivity growth (TE²-POLS)

\begin{tabular}{|c|c|c|c|c|}
\hline & \multicolumn{2}{|l|}{$\Delta \log \mathrm{LP}$} & \multicolumn{2}{|l|}{$\Delta \log$ TFP } \\
\hline & (1) & (2) & (3) & (4) \\
\hline & POLS & POLS & POLS & POLS \\
\hline$\overline{\Delta \text { Log Productivity }}{ }^{\mathrm{L}}$ & $\begin{array}{l}0.151 \\
(0.024) * * *\end{array}$ & $\begin{array}{l}0.158 \\
(0.024) * * *\end{array}$ & $\begin{array}{l}0.149 \\
(0.026) * * *\end{array}$ & $\begin{array}{l}0.150 \\
(0.026) * * *\end{array}$ \\
\hline Log Relative Productivity & $\begin{array}{l}-0.024 \\
(0.008)^{* * *}\end{array}$ & $\begin{array}{l}-0.022 \\
(0.009)^{* *}\end{array}$ & $\begin{array}{l}-0.020 \\
(0.012)^{*}\end{array}$ & $\begin{array}{l}-0.020 \\
(0.012)^{*}\end{array}$ \\
\hline EPL & $\begin{array}{l}0.008 \\
(0.003)^{* * *}\end{array}$ & $\begin{array}{l}0.010 \\
(0.003)^{* * *}\end{array}$ & $\begin{array}{l}0.011 \\
(0.003)^{* * *}\end{array}$ & $\begin{array}{l}0.011 \\
(0.003)^{* * *}\end{array}$ \\
\hline EPL*FJR & $\begin{array}{l}-0.126 \\
(0.052)^{* *}\end{array}$ & $\begin{array}{l}-0.169 \\
(0.053)^{* * *}\end{array}$ & $\begin{array}{l}-0.137 \\
(0.053)^{* * *}\end{array}$ & $\begin{array}{l}-0.144 \\
(0.053)^{* * *}\end{array}$ \\
\hline TE & $\begin{array}{l}-0.090 \\
(0.027)^{* * *}\end{array}$ & $\begin{array}{l}-0.054 \\
(0.026)^{* *}\end{array}$ & $\begin{array}{l}-0.082 \\
(0.027)^{* * *}\end{array}$ & $\begin{array}{l}-0.075 \\
(0.028)^{* * *}\end{array}$ \\
\hline $\mathrm{TE}^{2}$ & $\begin{array}{l}0.043 \\
(0.039)\end{array}$ & $\begin{array}{l}0.021 \\
(0.039)\end{array}$ & $\begin{array}{l}0.029 \\
(0.040)\end{array}$ & $\begin{array}{l}0.025 \\
(0.040)\end{array}$ \\
\hline TE*SSII & - & $\begin{array}{l}-0.068 \\
(0.017)^{* * *}\end{array}$ & - & $\begin{array}{l}-0.022 \\
(0.012)^{*}\end{array}$ \\
\hline TUD & $\begin{array}{l}-0.001 \\
(0.001)\end{array}$ & $\begin{array}{l}-0.001 \\
(0.000)\end{array}$ & $\begin{array}{c}-0.001 \\
(0.001)\end{array}$ & $\begin{array}{l}-0.001 \\
(0.000)\end{array}$ \\
\hline PMR & $\begin{array}{l}-0.001 \\
(0.000)^{* * *}\end{array}$ & $\begin{array}{l}-0.001 \\
(0.000)^{* * *}\end{array}$ & $\begin{array}{l}-0.001 \\
(0.001)\end{array}$ & $\begin{array}{l}-0.001 \\
(0.000)^{*}\end{array}$ \\
\hline CONSTANT & $\begin{array}{l}0.023 \\
(0.005)^{* * *}\end{array}$ & $\begin{array}{l}0.022 \\
(0.005)^{* * *}\end{array}$ & $\begin{array}{l}0.018 \\
(0.005)^{* * *}\end{array}$ & $\begin{array}{l}0.017 \\
(0.005)^{* * *}\end{array}$ \\
\hline COUNTRY DUMMIES & NO & NO & NO & NO \\
\hline YEAR DUMMIES & NO & NO & NO & NO \\
\hline Observations & 1950 & 1950 & 1800 & 1800 \\
\hline R-squared & 0.103 & 0.116 & 0.065 & 0.117 \\
\hline
\end{tabular}

$P O L S$ pooled ordinary least squares, $E P L$ employment protection legislation, $F J R$ frictionless job reallocation, $T E$ the share of temporary employment, TUD trade union density, $P M R$ product market regulation

HAC Robust standard errors in brackets

$*$ significant at $10 \%, * *$ significant at $5 \%, * * *$ significant at $1 \%$

product market regulation in the IV specification even in the shorter sample (i. e. 1992-2005) leads to a significantly lower effect of TE (i.e. -0.145). Overall, from our investigation we can conclude that the lower estimated effect of TE in our paper seems to be due especially to the inclusion of Schumpeterian variables and product market regulation in the productivity equation, while the different sample appears to explain only slightly the lower estimate of TE. ${ }^{21}$ Therefore, this seems to suggest that the estimated effects of TE in this paper are a little more cautious, as they control also for different factors affecting productivity.

Then, we wonder whether the estimated effects and, in particular, the differential effect of TE hold also using TFP as dependent variable. From the empirical perspective, the question is legitimate because there are indeed theoretical reasons for which labour market regulations might also affect capital accumulation, even if potentially in both positive and negative directions (Bertola 1994; Saint-Paul 2002; Samaniego 2006). Therefore, in columns (4) to (6) we re-

${ }^{21}$ Full regressions on this specific point are available upon requests from the authors. port the same estimates using TFP as productivity variable. Overall, we can see that fairly all the coefficients of interest are significant with the expected sign. In particular, the point estimates of TE and TE*SSII are negative and significant, confirming our result that TE is even more damaging in skilled sectors, with a negative effect on productivity growth significantly heavier than in unskilled sectors. Similarly, the estimates for EPL*FJR, as well as for the Schumpeterian growth variables, are also in line with our previous estimates.

Finally, as discussed in Sect. 3, while the reduced-form model (i.e. without capital-labour ratio) in Table 1 may allow to capture the overall effect of TE on labour productivity (OECD 2007; Bassanini and Venn 2008; Cappellari et al. 2012; Lisi 2013), omitting the capital-to-labour growth in the model for labour productivity could produce biased estimates (e.g., Levinson and Petrin 2003). Therefore, in order to provide a robust evidence on the differential effect of TE, in Table 2 we show the estimates of the model for labour productivity including the capital-to-labour growth as regressor. As we can see from Table 2, as expected the coefficient of the capital-to-labour growth is always sig- 
Table 4 Temporary employment and productivity growth $\left(\mathrm{TE}^{2}-\mathrm{FE}\right)$

\begin{tabular}{|c|c|c|c|c|}
\hline & \multicolumn{2}{|l|}{$\Delta \log \mathrm{LP}$} & \multicolumn{2}{|l|}{$\Delta \log$ TFP } \\
\hline & (1) & (2) & (3) & (4) \\
\hline & FE & FE & FE & FE \\
\hline$\overline{\Delta \text { Log Productivity }}{ }^{\mathrm{L}}$ & $\begin{array}{l}0.203 \\
(0.028) * * *\end{array}$ & $\begin{array}{l}0.198 \\
(0.028)^{* * *}\end{array}$ & $\begin{array}{l}0.198 \\
(0.031)^{* * *}\end{array}$ & $\begin{array}{l}0.197 \\
(0.031)^{* * *}\end{array}$ \\
\hline Log Relative Productivity & $\begin{array}{l}-0.023 \\
(0.009)^{* *}\end{array}$ & $\begin{array}{l}-0.020 \\
(0.008)^{* *}\end{array}$ & $\begin{array}{l}-0.043 \\
(0.011)^{* * *}\end{array}$ & $\begin{array}{l}-0.047 \\
(0.011)^{* * *}\end{array}$ \\
\hline EPL & $\begin{array}{l}0.009 \\
(0.010)\end{array}$ & $\begin{array}{l}0.010 \\
(0.007)^{*}\end{array}$ & $\begin{array}{l}0.007 \\
(0.009)\end{array}$ & $\begin{array}{l}0.007 \\
(0.009)\end{array}$ \\
\hline EPL*FJR & $\begin{array}{l}-0.129 \\
(0.052)^{* *}\end{array}$ & $\begin{array}{l}-0.133 \\
(0.049)^{* * *}\end{array}$ & $\begin{array}{l}-0.108 \\
(0.049)^{* *}\end{array}$ & $\begin{array}{l}-0.113 \\
(0.050)^{* *}\end{array}$ \\
\hline TE & $\begin{array}{l}-0.106 \\
(0.030)^{* * *}\end{array}$ & $\begin{array}{l}-0.080 \\
(0.031)^{* * *}\end{array}$ & $\begin{array}{l}-0.093 \\
(0.032) * * *\end{array}$ & $\begin{array}{l}-0.083 \\
(0.032)^{* *}\end{array}$ \\
\hline $\mathrm{TE}^{2}$ & $\begin{array}{l}0.044 \\
(0.044)\end{array}$ & $\begin{array}{l}0.018 \\
(0.042)\end{array}$ & $\begin{array}{l}0.053 \\
(0.044)\end{array}$ & $\begin{array}{l}0.050 \\
(0.044)\end{array}$ \\
\hline TE*SSII & - & $\begin{array}{l}-0.052 \\
(0.016)^{* * *}\end{array}$ & - & $\begin{array}{l}-0.055 \\
(0.032)^{*}\end{array}$ \\
\hline TUD & $\begin{array}{l}-0.002 \\
(0.001)^{*}\end{array}$ & $\begin{array}{l}-0.002 \\
(0.001)^{*}\end{array}$ & $\begin{array}{l}-0.002 \\
(0.001)^{*}\end{array}$ & $\begin{array}{l}-0.002 \\
(0.001)^{*}\end{array}$ \\
\hline PMR & $\begin{array}{l}-0.001 \\
(0.001)\end{array}$ & $\begin{array}{l}-0.001 \\
(0.001)\end{array}$ & $\begin{array}{l}-0.001 \\
(0.001)\end{array}$ & $\begin{array}{l}-0.001 \\
(0.001)\end{array}$ \\
\hline COUNTRY DUMMIES & YES & YES & YES & YES \\
\hline YEAR DUMMIES & YES & YES & YES & YES \\
\hline Observations & 1950 & 1950 & 1800 & 1800 \\
\hline R-squared & 0.186 & 0.193 & 0.103 & 0.104 \\
\hline
\end{tabular}

$F E$ fixed effects (dummy variable regression), $E P L$ employment protection legislation, $F J R$ frictionless job reallocation, $T E$ the share of temporary employment, TUD trade union density, $P M R$ product market regulation

HAC Robust standard errors in brackets

* significant at $10 \%, * *$ significant at $5 \%, * * *$ significant at $1 \%$

nificant in the reasonable range of $0.2-0.3$; however, even if the inclusion of the capital-labour ratio slightly changes the estimates, both TE and TE*SSII are still negative and significant with a magnitude close to those in Table 1. Overall, the inclusion of the capital-labour ratio in the empirical model for labour productivity, while it affects the estimated coefficients of some explanatory variable, it does not seem to change significantly our conclusion on the differential effect of TE on productivity.

\section{Robustness checks}

As discussed in Sect. 2, a few previous studies in this literature (Hirsch and Mueller 2012; Nielen and Schiersch 2014) find that TAW - i.e. a component of TE provided by EU Labour Force Survey - generates an inversely u-shaped effect in the user firms' productivity. This piece of evidence appears well-grounded in the argument that a low share of TAW within a firm could be a means of enhancing numerical flexibility (Vidal and Tigges 2009) and screening new workers (Autor 2001), whereas a high share of TAW could be a signal of a broader substitution between perms to temps, which is likely to lower the motivation and commitment of the workforce (Hirsch and Mueller 2012). Although this argument in an industry-level dataset is less clear, it is still important in our analysis to control for the presence of a non-linear effect of TE in the productivity equation, because the interaction term TE*SSII in our model (4) might pick up the effect of non-linearity of TE, thus leading to a wrong inference on the differential effect of TE among sectors. Therefore, in Table 3 and Table 4, respectively for POLS and FE models, we provide the estimates with the quadratic term of TE in the productivity equation, using both labour productivity and TFP as dependent variable.

In particular, in columns (1) and (3) of both tables, respectively for labour productivity and TFP, we estimate our productivity equation with the quadratic term of TE without the interaction term, to check for the presence of a nonlinear effect of TE. As we can see in Table 3 and Table 4, in all estimates the coefficient of the quadratic term results statistically insignificant; thus, they do not provide evidence of a non-linear effect of TE, at least in our industry-level panel. Then, in columns (2) and (4), respectively for labour productivity and TFP, we add also the interaction term TE*SSII, along with the quadratic term of TE. 
Table 5 Temporary employment and productivity growth (SSII2)

\begin{tabular}{|c|c|c|c|c|c|c|}
\hline & \multicolumn{3}{|l|}{$\Delta \log \mathrm{LP}$} & \multicolumn{3}{|l|}{$\Delta \log$ TFP } \\
\hline & (1) & (2) & (3) & (4) & (5) & (6) \\
\hline & POLS & FE & IV & POLS & FE & IV \\
\hline$\overline{\Delta \text { Log Productivity }}{ }^{\mathrm{L}}$ & $\begin{array}{l}0.152 \\
(0.023) * * *\end{array}$ & $\begin{array}{l}0.202 \\
(0.028) * * *\end{array}$ & - & $\begin{array}{l}0.149 \\
(0.026)^{* * *}\end{array}$ & $\begin{array}{l}0.211 \\
(0.030) * * *\end{array}$ & - \\
\hline Log Relative Productivity & $\begin{array}{l}-0.016 \\
(0.008)^{* *}\end{array}$ & $\begin{array}{l}-0.016 \\
(0.008)^{* *}\end{array}$ & $\begin{array}{l}-0.019 \\
(0.010) *\end{array}$ & $\begin{array}{l}-0.021 \\
(0.012)^{*}\end{array}$ & $\begin{array}{l}-0.032 \\
(0.014)^{* *}\end{array}$ & $\begin{array}{l}-0.019 \\
(0.012)^{*}\end{array}$ \\
\hline EPL & $\begin{array}{l}0.008 \\
(0.003) * * *\end{array}$ & $\begin{array}{l}0.010 \\
(0.007)^{*}\end{array}$ & $\begin{array}{l}0.008 \\
(0.002)^{* * *}\end{array}$ & $\begin{array}{l}0.012 \\
(0.003) * * *\end{array}$ & $\begin{array}{l}0.010 \\
(0.006)^{*}\end{array}$ & $\begin{array}{l}0.010 \\
(0.002) * * *\end{array}$ \\
\hline EPL*FJR & $\begin{array}{l}-0.146 \\
(0.051)^{* * *}\end{array}$ & $\begin{array}{l}-0.156 \\
(0.051)^{* * *}\end{array}$ & $\begin{array}{l}-0.095 \\
(0.028)^{* * *}\end{array}$ & $\begin{array}{l}-0.156 \\
(0.053)^{* * *}\end{array}$ & $\begin{array}{l}-0.165 \\
(0.053)^{* * *}\end{array}$ & $\begin{array}{l}-0.109 \\
(0.028)^{* * *}\end{array}$ \\
\hline TE & $\begin{array}{l}-0.053 \\
(0.017)^{* * *}\end{array}$ & $\begin{array}{l}-0.074 \\
(0.022)^{* *}\end{array}$ & $\begin{array}{l}-0.099 \\
(0.043)^{* * *}\end{array}$ & $\begin{array}{l}-0.056 \\
(0.015)^{* * *}\end{array}$ & $\begin{array}{l}-0.048 \\
(0.021)^{* *}\end{array}$ & $\begin{array}{l}-0.113 \\
(0.038)^{* * *}\end{array}$ \\
\hline TE*SSII2 & $\begin{array}{l}-0.048 \\
(0.016)^{* * *}\end{array}$ & $\begin{array}{l}-0.056 \\
(0.016)^{* * *}\end{array}$ & $\begin{array}{l}-0.021 \\
(0.011)^{* *}\end{array}$ & $\begin{array}{l}-0.037 \\
(0.016)^{* *}\end{array}$ & $\begin{array}{l}-0.040 \\
(0.016)^{* *}\end{array}$ & $\begin{array}{l}-0.014 \\
(0.009)^{*}\end{array}$ \\
\hline TUD & $\begin{array}{l}-0.001 \\
(0.001)_{-}\end{array}$ & $\begin{array}{l}-0.002 \\
(0.001)^{*}\end{array}$ & $\begin{array}{l}-0.005 \\
(0.003)^{*}\end{array}$ & $\begin{array}{l}-0.001 \\
(0.001)_{-}\end{array}$ & $\begin{array}{l}-0.002 \\
(0.001)^{*}\end{array}$ & $\begin{array}{l}-0.002 \\
(0.003)_{-}\end{array}$ \\
\hline PMR & $\begin{array}{l}-0.001 \\
(0.000)^{* *}\end{array}$ & $\begin{array}{l}-0.001 \\
(0.001)_{-}\end{array}$ & $\begin{array}{l}-0.006 \\
(0.003)^{* * *}\end{array}$ & $\begin{array}{l}-0.001 \\
(0.001)_{-}\end{array}$ & $\begin{array}{l}-0.001 \\
(0.001)_{-}\end{array}$ & $\begin{array}{l}-0.001 \\
(0.002)_{-}\end{array}$ \\
\hline CONSTANT & $\begin{array}{l}0.022 \\
(0.005)^{* * *}\end{array}$ & - & - & $\begin{array}{l}0.015 \\
(0.005)^{* * *}\end{array}$ & - & - \\
\hline COUNTRY DUMMIES & NO & YES & YES & NO & YES & YES \\
\hline YEAR DUMMIES & NO & YES & YES & NO & YES & YES \\
\hline SECTOR DUMMIES & NO & NO & YES & NO & NO & YES \\
\hline Observations & 1950 & 1950 & 1950 & 1800 & 1800 & 1800 \\
\hline R-squared & 0.102 & 0.189 & 0.432 & 0.126 & 0.186 & 0.249 \\
\hline
\end{tabular}

$P O L S$ pooled ordinary least squares, $F E$ fixed effects (dummy variable regression), $I V$ instrumental variable, $E P L$ employment protection legislation, FJR frictionless job reallocation, $T E$ the share of temporary employment, $T U D$ trade union density, $P M R$ product market regulation

HAC Robust standard errors in brackets

$*$ significant at $10 \%, * *$ significant at $5 \%, * * *$ significant at $1 \%$

Again, both in Table 3 and Table 4, the coefficients of the quadratic term are statistically insignificant, while those of TE*SSII are still negative and significant, confirming the higher negative effect of TE in skilled sectors. Overall, our findings would suggest that, at least in our industrylevel dataset, there is no evidence of a non-linear productivity effect of TE, regardless of the productivity measure employed as dependent variable as well as the estimated model. ${ }^{22}$ More importantly, the evidence in Table 3 and Table 4 provides further support to our inference on the

\footnotetext{
22 Even if we do not find evidence of a non-linear effect of TE, our results should not be interpreted as in contrast with the previous studies finding an inversely u-shaped effect of TE in the user firms' productivity (Hirsch and Mueller 2012; Nielen and Schiersch 2014). Notice that, in fact, while the above-mentioned argument on the inversely $\mathrm{u}$-shaped effect of TAW is certainly reasonable at the firm level, it is much less clear at the industry level. Therefore, it is not surprising that in our industry-level panel we do not find evidence of a non-linear effect of TE, but clearly this does not mean that at the firm level the inversely $\mathrm{u}$-shaped argument is not valid. Moreover, while the evidence on the inversely u-shaped productivity effect is strong for TAW, Nielen and Schiersch (2016) find that the same inversely u-shaped effect does not seem to emerge for fixed-term contracts, even at the firm level.
}

interaction term TE*SSII as the differential effect of TE among sectors.

As for the sectors' skill intensity index, to the extent that a subdivision between skilled and unskilled sectors has to be necessarily based on discretional criteria, in Table 5 we repeat the same estimates using a second sectors' skill intensity index, concerning the kind of task workers make in their job (see Appendix A). This second index leads to a similar, but slightly different, subdivision of sectors and, therefore, represents a perfect candidate to test the stability of our findings. As can be clearly seen from Table 5, this change in the SSII used in the estimation does not change our conclusions. Still, the coefficients of TE and TE*SSII2 are negative and significant, even with a magnitude very close to those in Table 1. Looking at the other explanatory variables, we can also see from Table 5 that the use of SSII2 does not change markedly the estimated effects..$^{23}$

Finally, to check whether our results depend crucially on the inclusion of some countries in the sample, we re-esti-

\footnotetext{
${ }^{23}$ We have also estimated the specifications with SSII2 (available upon request) with the capital-to-labour growth as regressor for labour productivity, with results fully in line with those presented in Table 2.
} 
REDUCED SAMPLE FE

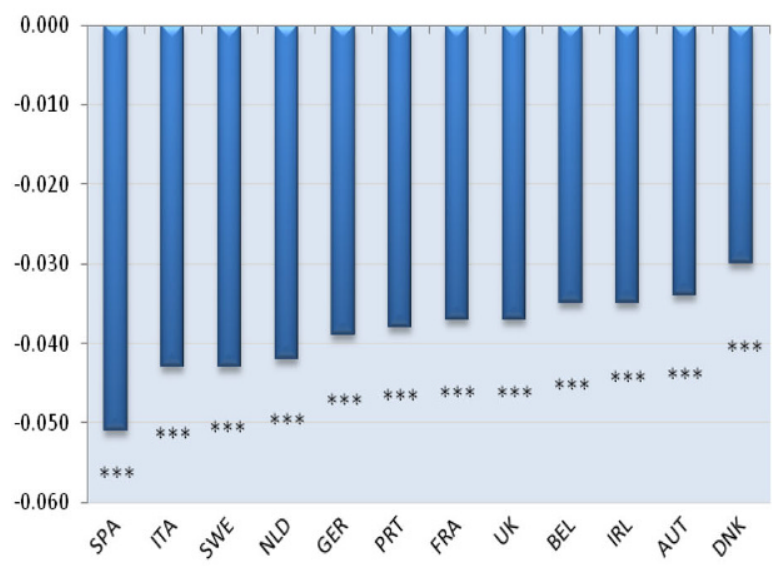

REDUCED SAMPLE IV

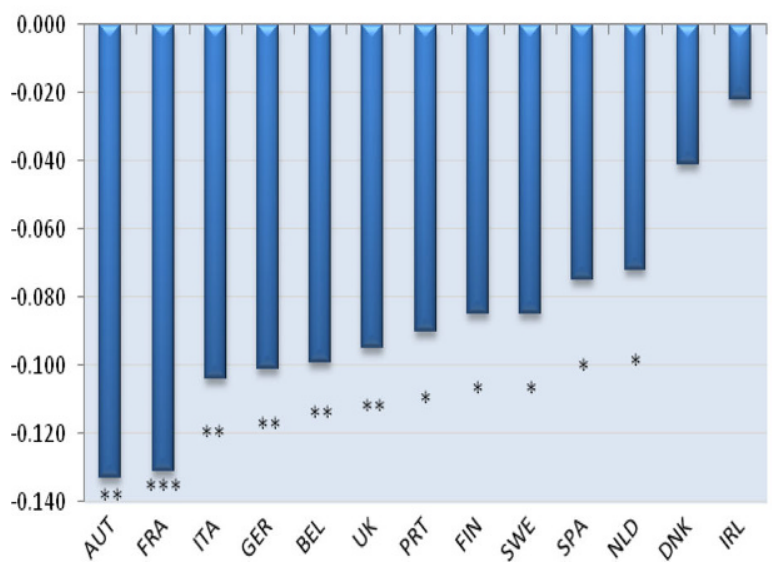

Fig. 2 Coefficients of TE and TE*SSII from the Reduced Sample

mate the model excluding all countries one-by-one. Therefore, we run many FE and IV regressions, using labour productivity as productivity variable ${ }^{24}$, where in each regression we exclude one different country. Indeed, this further robustness check should be especially relevant for the issue of temporary contracts, since we have already seen in Sect. 4 that the extent of TE is not homogeneous across EU countries (see also, e. g., Boeri and Garibaldi 2007). In particular, the inclusion of Spain and Portugal in the sample might potentially be important in driving our results, as both countries not only have had the highest share of temporary contracts for many years, but also they have implemented reforms reducing considerably the protection of permanent workers. In Fig. 2 are the coefficients of TE and TE*SSII, arranged from the greatest to the smallest, for both FE and IV. ${ }^{25}$

\footnotetext{
${ }^{24}$ We have also run the same reduced sample regressions (available upon request) using TFP as productivity variable, with results fully in line with those presented in Fig. 2.

${ }^{25}$ Full regressions are available upon request from the authors.
}

\section{REDUCED SAMPLE FE}

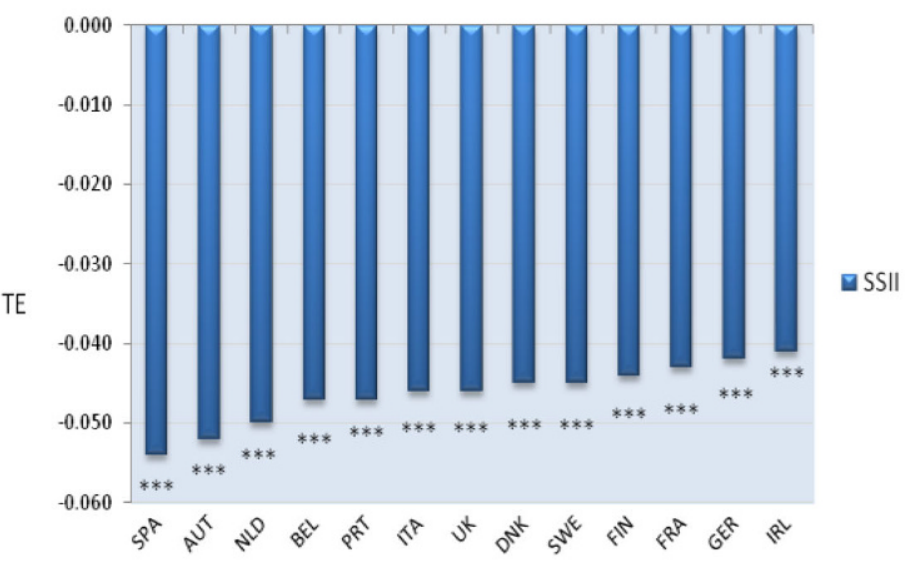

REDUCED SAMPLE IV

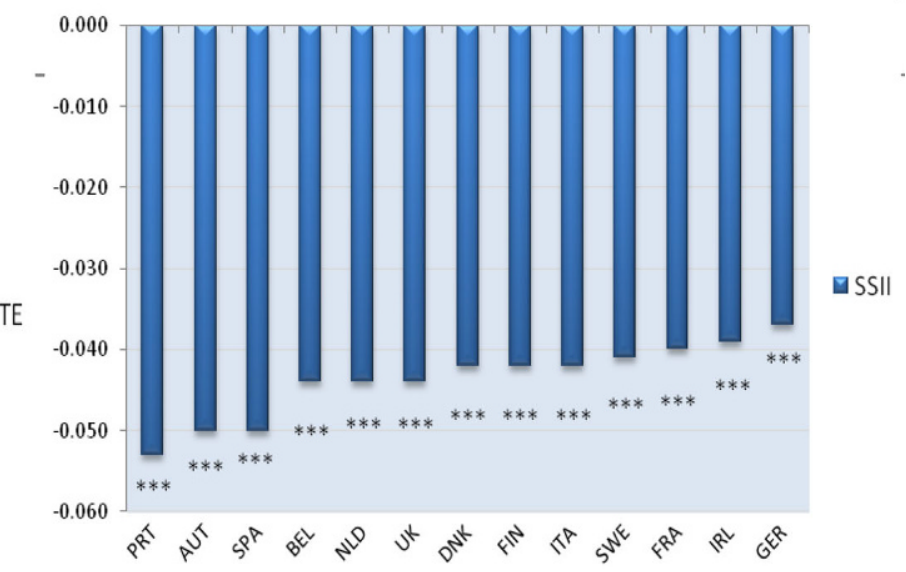

As Fig. 2 clearly shows, however, our results do not depend on the sample of countries included in the estimation. Indeed, both the coefficients of TE and TE*SSII are fairly always negative and significant, even omitting Spain and Portugal. Furthermore, the magnitude of the coefficients would seem to validate sufficiently our result that TE is even more damaging in skilled sectors, with a negative effect significantly heavier than in unskilled sectors.

\section{Conclusions}

In this paper we have studied the effect of the share of TE on productivity, explicitly considering the differential effect in skilled and unskilled economic sectors. Our industry-level panel of EU countries allowed to disentangle the effect of the share of TE between skilled and unskilled sectors, controlling also for different unobserved confounding factors and the potential endogeneity of the share of TE in the productivity equation. As discussed in the paper, the empirical analysis on this question appears to be important, 
given that from a theoretical point of view is ambiguous what sectors might be more affected by the use of temporary employment.

The main finding of the paper is that TE is even more damaging in skilled sectors, with a negative effect significantly heavier than in unskilled sectors, robust to little changes in the skill intensity index and in the sample used, as well as to the inclusion of non-linearity in the effect of TE. In particular, we find that an increase of 10 percentage points of the share of TE in skilled sectors would lead to a decrease of about $1-1.5 \%$ in labour productivity growth, whereas in unskilled ones the reduction would be only of $0.5-0.8 \%$. Finally, we find similar results in the productivity equations with TFP growth as dependent variable.

Apart from offering a more accurate description of the impact of TE, these results have important policy implications and, certainly, lead us to question if the actual European regulation corresponds exactly to the lines of the best practice. In particular, this evidence might support the growing feeling that TE is currently used in fairly all industries more as a regular form of job to save on firms' wage bill, much beyond the role of screening device (Booth et al. 2002; Güell and Petrongolo 2007; Garz 2013). Consequently, temporary employment seem to be related with permanently high levels of workers' rotation, damaging productivity in all sectors but especially in skilled sectors, where production uses skills more intensively. Therefore, in line with recent literature on flexibilization and productivity (e. g., Lisi 2013; Kleinknecht et al. 2014; Vergeer and Kleinknecht 2014), we also conclude that the extensive use of flexible labour is not a free lunch not only for firms, but also for the society as a whole.

The main regulatory implication raising from this picture is that the real challenge for labour regulation is to find a design to address the use of temporary employment as a flexible way to enter in the market allowing firms to screen new workers towards more stable form of jobs, instead of as a structural cheaper form of work. Probably, only in those conditions labour market outcomes could be able to benefit from all the advantages in terms of flexibility induced by TE, without suffering the secondary consequences on labour productivity. Hence, the future agenda of labour market research should certainly include the identification of such kind of regulation.

As discussed in the paper, the potential limitation of our analysis is that, indeed, the employed measure of TE does not allow us to distinguish between fixed-term contracts and temporary agency workers, which instead might be relevant as the two types of TE might (and often are found to) have different effects in the user firm's productivity. Under this perspective, disentangling the differential effect of these two types of TE would represent the next step on our understanding of the productivity effect of TE and, thus, a bit of caution in the interpretation of our results is needed. Due to data limitation, however, this is left for future research.

Acknowledgements The authors would like to thank Stephen Machin, Roberto Cellini, two anonymous referees and participants in various conferences and seminars for helpful comments and suggestions. Miguel A. Malo acknowledges funding from the Spanish Ministry of Economy and Competitiveness (research project CSO2014-59927-R). The usual disclaimer applies.

Open Access This article is distributed under the terms of the Creative Commons Attribution 4.0 International License (http:// creativecommons.org/licenses/by/4.0/), which permits unrestricted use, distribution, and reproduction in any medium, provided you give appropriate credit to the original author(s) and the source, provide a link to the Creative Commons license, and indicate if changes were made.

\section{Appendix A: Data description}

The majority of variables employed in the paper (e.g., labour productivity, share of TE, EPL index for PE and TE) are drawn from Lisi (2013), please refer to Lisi (2013) for a full description of the dataset and the source of variables. Hereunder, we provide the description only of the new variables in our empirical analysis.

\section{Total Factor Productivity}

Definition. Total factor productivity (base $1995=100$ ) (variable TFPva_I).

Source. EU KLEMS database.

\section{Capital Stock}

Definition. Gross capital stock in volume terms (variable $C P G K)$.

Source. OECD STAN database.

\section{Share of skilled workers in SSII}

Definition. Share of workers with a tertiary education (level 5-6 ISCED 1997).

Source. EUROSTAT Science, technology and innovation database.

\section{Share of skilled workers in SSII2}

Definition. Share of workers occupied in science and technology tasks (HRST). 
Source. EUROSTAT Science, technology and innovation database.

\section{Product Market Regulation}

Definition. OECD Indicators of Product Market Regulation, a comprehensive set of indicators measuring the degree to which policies promote or inhibit competition in areas of the product market where competition is viable. The indicators cover formal regulations in the following areas: state control of business enterprises; legal and administrative barriers to entrepreneurship; barriers to international trade and investment.

Source. OECD database. 


\section{Appendix B: Descriptive statistics}

Table B.1 Descriptive statistics

\begin{tabular}{|c|c|c|c|c|c|}
\hline Variable & Obs & Mean & Std. Dev & Min & Max \\
\hline Labour Productivity & 2080 & 110.936 & 24.237 & 63.486 & 286.575 \\
\hline Labour Productivity Growth & 1950 & 0.018 & 0.051 & -0.322 & 0.288 \\
\hline Total Factor Productivity & 1920 & 103.742 & 15.522 & 61.629 & 199.388 \\
\hline Total Factor Productivity Growth & 1800 & 0.006 & 0.047 & -0.312 & 0.350 \\
\hline Capital-Labour ratio & 1600 & $754,330.1$ & $2,222,605$ & $11,961.45$ & $23,719,022$ \\
\hline Capital-Labour ratio growth & 1500 & 0.015 & 0.030 & -0.102 & 0.241 \\
\hline Job Reallocation & 1950 & 0.027 & 0.026 & 0.000 & 0.239 \\
\hline Frictionless Job Reallocation & 2080 & 0.043 & 0.009 & 0.028 & 0.059 \\
\hline Share of TE & 2080 & 0.118 & 0.103 & 0.000 & 0.694 \\
\hline EPL for Regular Contracts & 2080 & 2.376 & 0.826 & 0.948 & 4.333 \\
\hline EPL for Temporary Contracts & 2080 & 2.189 & 1.255 & 0.250 & 5.375 \\
\hline Trade Union Density & 2080 & 0.402 & 0.229 & 0.076 & 0.839 \\
\hline Product Market Regulation & 2080 & 1.696 & 0.481 & 0.771 & 2.528 \\
\hline
\end{tabular}

Table B.2 Industry descriptive statistics

\begin{tabular}{|c|c|c|c|c|c|}
\hline \multicolumn{2}{|c|}{ Industry } & $\overline{\mathrm{TE}}_{j}$ & $\overline{L P}_{j}$ & $\overline{\mathrm{TFP}}_{j}$ & $F J R_{j}$ \\
\hline \multicolumn{2}{|c|}{ Agriculture, Hunting and Forestry } & 0.2048 & 117.1452 & 113.3016 & 0.049 \\
\hline \multicolumn{2}{|c|}{ Total Manufacturing } & 0.0891 & 119.5393 & 107.4631 & 0.038 \\
\hline \multicolumn{2}{|c|}{ Electricity, Gas and Water Supply } & 0.0631 & 126.7167 & 110.3447 & 0.059 \\
\hline \multicolumn{2}{|c|}{ Construction } & 0.1400 & 100.1263 & 97.8735 & 0.045 \\
\hline \multicolumn{2}{|c|}{ Wholesale and Retail Trade } & 0.1046 & 110.8905 & 104.1041 & 0.028 \\
\hline \multicolumn{2}{|c|}{ Hotels and Resturants } & 0.1761 & 100.0441 & 97.1390 & 0.040 \\
\hline \multicolumn{2}{|c|}{ Transport, Storage and Communication } & 0.0827 & 117.4543 & 108.4009 & 0.036 \\
\hline \multicolumn{2}{|c|}{ Financial Intermediation } & 0.0633 & 120.8515 & 106.3441 & 0.039 \\
\hline \multicolumn{2}{|c|}{ Real Estate, Renting and Business Activities } & 0.0932 & 96.2325 & 97.1183 & 0.057 \\
\hline \multicolumn{2}{|c|}{ Other Community, Social and Personal Services } & 0.1679 & 100.3553 & 95.3268 & 0.040 \\
\hline \multirow[t]{4}{*}{$\rho_{j}$} & - & $\overline{\mathrm{TE}}$ & $\overline{L P}$ & $\overline{\mathrm{TFP}}$ & - \\
\hline & $\overline{\mathrm{TE}}$ & 1 & -0.4836 & -0.2481 & - \\
\hline & $\overline{L P}$ & -0.4836 & 1 & 0.9130 & \\
\hline & $\overline{T F P}$ & -0.2481 & 0.9130 & 1 & \\
\hline
\end{tabular}


Table B.3 Country descriptive statistics

\begin{tabular}{|c|c|c|c|c|}
\hline$\overline{\text { Country }}$ & & $\overline{\mathrm{TE}}_{i}$ & $\overline{L P}_{i}$ & $\overline{\mathrm{TFP}}_{i}$ \\
\hline Austria & & 0.0631 & 109.6844 & 106.0690 \\
\hline Belgium & & 0.0545 & 108.1211 & 101.0587 \\
\hline Denmark & & 0.0936 & 105.5621 & 98.1947 \\
\hline Finland & & 0.1289 & 112.1675 & 108.3581 \\
\hline France & & 0.1245 & 112.1939 & 106.8663 \\
\hline Germany & & 0.1164 & 110.7430 & 107.3981 \\
\hline Ireland & & 0.0626 & 119.8140 & 106.7250 \\
\hline Italy & & 0.1079 & 102.9484 & 98.2979 \\
\hline Netherlands & & 0.1374 & 111.0894 & 103.6141 \\
\hline Portugal & & 0.1624 & 116.6231 & 103.7416 \\
\hline Spain & & 0.3241 & 105.3882 & 98.8157 \\
\hline Sweden & & 0.1061 & 112.1912 & 104.4574 \\
\hline United Kingdom & & 0.0588 & 115.6359 & 105.0443 \\
\hline \multirow[t]{4}{*}{$\rho_{i}$} & - & $\overline{\mathrm{TE}}$ & $\overline{L P}$ & $\overline{\mathrm{TFP}}$ \\
\hline & $\overline{\mathrm{TE}}$ & 1 & -0.2972 & -0.3224 \\
\hline & $\overline{L P}$ & -0.2972 & 1 & 0.7256 \\
\hline & $\overline{\mathrm{TFP}}$ & -0.3224 & 0.7256 & 1 \\
\hline
\end{tabular}

Table B.4 Temporary agency workers (TAW)

\begin{tabular}{|c|c|c|c|c|c|c|}
\hline \multirow[t]{2}{*}{$\overline{\text { Country }}$} & \multicolumn{3}{|c|}{ Share of TAW over total employment ${ }^{\mathrm{a}}$} & \multicolumn{3}{|c|}{ Share of TAW over total TE } \\
\hline & 1997 & 2002 & 2007 & 1997 & 2002 & 2007 \\
\hline Austria & 0.005 & 0.008 & 0.015 & 0.064 & 0.108 & 0.170 \\
\hline Belgium & 0.013 & 0.016 & 0.022 & 0.206 & 0.211 & 0.256 \\
\hline Denmark & 0.002 & 0.004 & 0.008 & 0.018 & 0.045 & 0.089 \\
\hline Finland & 0.004 & 0.005 & 0.011 & 0.023 & 0.029 & 0.069 \\
\hline France & 0.016 & 0.024 & 0.025 & 0.133 & 0.170 & 0.166 \\
\hline Germany & 0.005 & 0.007 & 0.016 & 0.042 & 0.058 & 0.109 \\
\hline Ireland & 0.003 & 0.014 & 0.017 & 0.032 & 0.286 & 0.200 \\
\hline Italy & n.1.r. & 0.004 & 0.010 & n.1.r. & 0.040 & 0.076 \\
\hline Netherlands & 0.023 & 0.021 & 0.028 & 0.204 & 0.148 & 0.156 \\
\hline Portugal & 0.006 & 0.009 & 0.009 & 0.048 & 0.041 & 0.040 \\
\hline Spain & 0.007 & 0.007 & 0.008 & 0.021 & 0.022 & 0.025 \\
\hline Sweden & 0.004 & 0.009 & 0.013 & 0.034 & 0.059 & 0.076 \\
\hline United Kingdom & 0.029 & 0.038 & 0.048 & 0.397 & 0.633 & 0.842 \\
\hline
\end{tabular}

n.l.r. not legally recognised

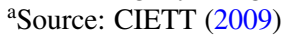

Table B.5 Skilled and unskilled sectors produced by "SSII"

\begin{tabular}{ll}
\hline Skilled sectors & Unskilled sectors \\
\hline Manufacturing & Agriculture, hunting and forestry \\
Wholesale and retail trade & Electricity, gas and water supply \\
Hotels and restaurants & Construction \\
Financial intermediation & Transport, storage and communication \\
Real estate, renting and business activities & Other community, social and personal services \\
\hline
\end{tabular}


Table B.6 Skilled and unskilled sectors produced by "SSII2"

\begin{tabular}{ll}
\hline Skilled sectors & Unskilled sectors \\
\hline Manufacturing & Agriculture, hunting and forestry \\
Wholesale and retail trade & Electricity, gas and water supply \\
Financial intermediation & Construction \\
Real estate, renting and business activities & Hotels and restaurants \\
Other community, social and personal services & Transport, storage and communication \\
\hline
\end{tabular}

\section{References}

Aghion, P., Howitt, P.: Appropriate growth policy: a unifying framework. J Eur Econ Assoc 4, 269-314 (2006)

Aghion, P., Algan, Y., Cahuc, P., Shleifer, A.: Regulation and distrust. Q J Econ 125, 1015-1049 (2010)

Alba-Ramirez, A.: Formal training, temporary contracts, productivity and wages in Spain. Oxf Bull Econ Stat 56, 151-170 (1994)

Albert, C., Garcia-Serrano, C., Hernanz, V.: Firm-provided training and temporary contracts. Span Econ Rev 7, 67-88 (2005)

Albert, C., Garcia-Serrano, C., Hernanz, V.: On-the-job training in Europe: determinants and wage returns. Int Labour Rev 149, 315-341 (2010)

Amable, B., Ledezma, I.: Export performance and product market regulation. Reg Dev 37, 231-258 (2013)

Arvanitis, S.: Modes of labor flexibility at firm level: Are there any implications for performance and innovation? Evidence for the Swiss economy. Ind Corp Change 14, 993-1016 (2005)

Auer, P., Berg, J., Coulibaly, I.: Is a stable workforce good for productivity? Int Labour Rev 144, 319-343 (2005)

Autor, D.: Why do temporary help firms provide free general skills training? Q J Econ 116, 1409-1448 (2001)

Autor, D., Housman, S.N.: Do temporary-help jobs improve labor market outcomes for low-skilled workers? Evidence from 'work first. Am Econ J Appl Econ 2, 96-128 (2010)

Bassanini, A., Venn, D.: Assessing the impact of labour market policies on productivity: a difference-in-differences approach. OECD Social Employment and Migration Working Papers, No. 54. OECD Publishing., Paris (2007)

Bassanini, A., Venn, D.: The impact of labour market policies on productivity in OECD countries. Int Prod Monit 17, 3-15 (2008)

Bassanini, A., Booth, A., Brunello, G., De Paola, M., Leuven, E.: Workplace training in Europe. IZA Discussion Papers 1640. (2005)

Bassanini, A., Nunziata, L., Venn, D.: Job protection legislation and productivity growth in OECD countries. Econ Policy 24, 349-402 (2009)

Baum, C.F., Schaffer, M.E., Stillman, S.: Enhanced routines for instrumental variables/generalized method of moments estimation and testing. Stata J 7, 465-506 (2007)

Bentolila, S., Saint-Paul, G.: The macroeconomic impact of flexible labor contracts, with an application to Spain. Eur Econ Rev 36, 1013-1047 (1992)

Bertola, G.: Flexibility, investment, and growth. J Monet Econ 34, 215-238 (1994)

Boeri, T., Garibaldi, P.: Two tier reforms of employment protection: a honeymoon effect? Econ J 117, F357-F385 (2007)

Boeri, T., Garibaldi, P.: Beyond Eurosclerosis. Econ Policy 24, 409-461 (2009)

Booth, A., Francesconi, M., Frank, J.: Temporary jobs: stepping stones or dead ends? Econ J 112, 189-213 (2002)

Bryson, A.: Do temporary agency workers affect workplace performance? J Prod Analysis 39, 131-138 (2013)
Buchele, R., Christiansen, J.: Employment and productivity growth in Europe and North America: the impact of labour market institutions. Int Rev Appl Econ 13, 313-332 (1999)

Cappellari, L., Dell'Aringa, C., Leonardi, M.: Temporary employment, job flows and productivity: a tale of two reforms. Econ J 122, F188-F215 (2012)

Cazes, S., Tonin, M.: Employment protection legislation and job stability: a European cross-country analysis. Int Labour Rev 149, 261-285 (2010)

Charron, N., Dijkstra, L., Lapuente, V.: Regional governance matters: quality of government within European Union member states. Reg Stud 48, 68-90 (2014)

Charron, N., Dijkstra, L., Lapuente, V.: Mapping the regional divide in Europe: a measure for assessing quality of government in 206 European regions. Soc Indic Res 122, 315-346 (2015)

Ciccone, A., Papaioannou, E.: Adjustment to target capital, finance and growth. CEPR Discussion Papers No. 5969. (2006)

CIETT: The agency work industry around the world. CIETT, Brussels (2009)

Cingano, F., Leonardi, M., Messina, J., Pica, G.: The effect of employment protection legislation and financial market imperfections on investment: evidence from a firm-level panel of EU countries. Econ Policy 25, 117-163 (2010)

Damiani, M., Pompei, F.: Labour protection and productivity in EU economies: 1995-2005. Eur J Comp Econ 7, 373-411 (2010)

Dolado, J.J., Ortigueira, S., Stucchi, R.: Does dual employment protection affect TFP? Evidence from Spanish manufacturing firms. J Span Econ Assoc 7(4), 421-459 (2016)

Eichhorst, W., Tobsch, V.: Not so standard anymore? Employment duality in Germany. J Labour Mark Res 48(2), 81-95 (2015)

Engellandt, A., Riphahn, R.: Temporary contracts and employee effort. Labour Econ 12, 281-299 (2005)

Garz, M.: Employment and wages in Germany since the 2004 deregulation of the temporary agency industry. Int Labour Rev 152, 307-326 (2013)

Goux, D., Maurin, E., Pauchet, M.: Fixed-term contracts and the dynamics of labour demand. Eur Econ Rev 45, 533-552 (2001)

Griffith, R., Redding, S., Van Reenen, J.: Mapping the two faces of R\&D: productivity growth in a panel of OECD industries. Rev Econ Stat 86, 883-895 (2004)

Griffith, R., Redding, S., Simpson, H.: Technological catch-up and geographic proximity. J Reg Sci 49, 689-720 (2009)

Güell, M., Petrongolo, B.: How binding are legal limits? Transitions from temporary to permanent work in Spain. Labour Econ 14, 153-183 (2007)

Hagen, T.: Does fixed-term contract employment raise firms' adjustment speed? Evidence form an establishment panel for West Germany. J Econ Stat 223, 403-421 (2003)

Haskel, J.E., Slaughter, M.J.: Does the sector bias of skill-biased technical change explain changing skill premia? Eur Econ Rev 46, 1757-1783 (2002)

Hirsch, B., Mueller, S.: The productivity effect of temporary agency work: evidence from German panel data. Econ J 122, F216-F235 (2012) 
Houseman, S.N.: Why employers use flexible staffing arrangements: evidence from an establishment survey. Ind Labor Relat Rev 55, 149-170 (2001)

Ichino, A., Riphahn, R.T.: The effect of employment protection on worker effort: absenteeism during and after probation. J Eur Econ Assoc 3, 120-143 (2005)

International Labour Organization: World Employment and Social Outlook: Trends 2016. International Labour Organization, Geneva (2016)

International Monetary Fund: World Economic Outlook. Washington, (2007)

Jimeno, J.F., Toharia, L.: Effort, absenteeism, and fixed term employment contracts. Rev Esp De Econ 13, 105-119 (1996)

Kleinknecht, A.: Is labour market flexibility harmful to innovation? Cambridge J Econ 22, 387-396 (1998)

Kleinknecht, A., Oostendorp, R.M., Pradhan, M.P., Naastepad, C.W.M. Flexible labour, firm performance and the Dutch job creation miracle. Int Rev Appl Econ 20, 171-187 (2006)

Kleinknecht, A., Van Schaik, F.N., Zhou, H.: Is flexible labour good for innovation? Evidence from firm-level data. Cambridge J Econ 38, 1207-1219 (2014)

Kvasnicka, M.: Does temporary help work provide a stepping stone to regular employment? In: Autor, D.H. (ed.) Studies of labour market intermediation. University of Chicago Press, Chicago (2009)

Levinson, J., Petrin, A.: Estimating production functions using inputs to control for Unobservables. Rev Econ Stud 70, 317-341 (2003)

Lisi, D.: Analysis of employment protection legislation: a model with endogenous labour productivity. J Acad Res Econ 4, 209-245 (2012)

Lisi, D.: The impact of temporary employment and employment protection on labour productivity: evidence from an industry-level panel of EU countries. J Labour Mark Res 46(2), 119-144 (2013)

Lorenz, E.H.: Trust, contract and economic cooperation. Cambridge J Econ 23, 301-315 (1999)

Lucidi, F., Kleinknecht, A.: Little innovation, many jobs: an econometric analysis of the italian labour productivity crisis. Cambridge $\mathrm{J}$ Econ 34, 525-546 (2010)

MacLeod, W.B., Navakachara, V.: Can wrongful discharge law enhance employment? Econ J 117, 218-278 (2007)

Malo, M.A., Sánchez-Sánchez, N.: The legal form of labour conflicts and their time persistence: an empirical analysis with a large firms' panel. Eur J Law Econ 12, 513-533 (2014)

McGinnity, F., Mertens, A.: Wages and wage growth of fixed-term workers in East and West Germany. Appl Econ Q 50, 139-163 (2004)

Michie, J., Sheehan, M.: Labour market deregulation, 'flexibility' and innovation. Cambridge J Econ 27, 123-143 (2003)

Naastepad, C.W.M., Storm, S.: The innovating firm in a societal context: labour-management relations and labor productivity. In: Verburg, R.M., Ortt, J.R., Dicke, W.M. (eds.) Management technology and innovation: an introduction. Routledge, London (2006)

Nicoletti, G., Scarpetta, S.: Regulation, productivity and growth: OECD evidence. Econ Policy 18, 9-72 (2003)

Nielen, S., Schiersch, A.: Temporary agency work and firm competitiveness: evidence from German manufacturing firms. Ind Relat (Berkeley) 53, 365-393 (2014)

Nielen, S., Schiersch, A.: Productivity in German manufacturing firms: does fixed-term employment matter? Int Labour Rev (2016). doi:10.1111/ilr.12019

OECD: The OECD jobs study: evidence and explanations. OECD, Paris (1994)

OECD: Employment outlook. OECD, Paris (1999)
OECD: Employment outlook. OECD, Paris (2003)

OECD: Employment outlook. OECD, Paris (2004)

OECD: Employment outlook. OECD, Paris (2007)

OECD: Society at a glance 2011: OECD social indicators. OECD, Paris (2011)

OECD: Employment outlook. OECD, Paris (2015)

Ortega, B., Marchante, A.: Temporary contracts and labour productivity in Spain: a sectoral analysis. J Prod Anal 34, 199-212 (2010)

Rajan, R., Zingales, L.: Financial dependence and growth. Am Econ Rev 88, 559-586 (1998)

Saint-Paul, G.: Employment protection, international specialization, and innovation. Eur Econ Rev 46, 375-395 (2002)

Samaniego, R.: Employment protection and high-tech aversion. Rev Econ Dyn 9, 224-241 (2006)

Stock, J., Yogo, M.: Testing for weak instruments in linear IV regression. In: Stock, J., Andrews, D.W. (eds.) Identification and inference for econometric models. Cambridge University Press, New York (2005)

Tabellini, G.: Institutions and culture: presidential address. J Eur Econ Assoc 6, 255-294 (2008)

Tabellini, G.: Culture and institutions: economic development in the regions of Europe. J Eur Econ Assoc 8, 677-716 (2010)

Vergeer, R., Kleinknecht, A.: The impact of labour market deregulation on productivity: a panel data analysis of 19 OECD countries (1960-2004). J Post Keynes Econ 33, 371-407 (2011)

Vergeer, R., Kleinknecht, A.: Do labour market reforms reduce labour productivity growth? A panel data analysis of 20 OECD countries (1960-2004). Int Labour Rev 153, 365-393 (2014)

Vidal, M., Tigges, L.M.: Temporary employment and strategic staffing in the manufacturing sector. Ind Relat (Berkeley) 48, 55-72 (2009)

Walwei, U.: Times of change: what drives the growth of work arrangements in Germany? J Labour Mark Res 47(3), 183-204 (2014)

Wang, R., Weiss, A.: Probation, layoffs, and wage-tenure profiles: a sorting explanation. Labour Econ 5, 359-383 (1998)

Zhou, H., Dekker, R., Kleinknecht, A.: Flexible labor and innovation performance: Evidence from longitudinal firm-level data. Ind Corp Chang 20, 941-968 (2011)

Domenico Lisi is Postdoctoral Researcher of Public Economics in the Department of Economics and Business at the University of Catania and research affiliate of the Health Econometric and Data Group (HEDG) of the University of York. He obtained the Laurea in Economics (2005) and the Master of Arts in Economics (2007) at the University of Catania, the Master of Science in Economics (2009) at the University College London and the PhD in Public Economics (2011) at the University of Catania. His research interests include theoretical and empirical aspects of labour economics, health economics and applied economics.

Miguel A. Malo is Associate Professor of Economics at the University of Salamanca (Spain). Along 2013 he worked as Senior Economist at the Research Department of the International Labour Organization (Geneva, Switzerland). He has been a visiting scholar at UMIST (University of Manchester Institute of Science and Technology, UK), ECASS (European Centre for Analysis in the Social Sciences, Essex University, UK), and NBER (National Bureau of Economic Research, USA). From 2007 to 2009 he was President of the Spanish Association for Labour Economics. His main research interests are evaluation of active labour market policies, analysis of labour market reforms, and non-standard forms of employment. 